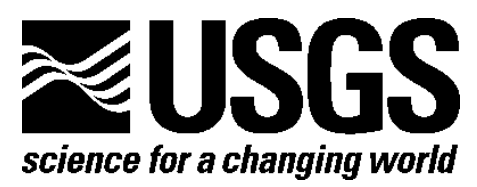

Prepared in cooperation with the New Hampshire Department of Environmental Services

Evaluation of Modeling for Groundwater Flow and Tetrachloroethylene Transport in the Milford-Souhegan Glacial-Drift Aquifer at the Savage Municipal Well Superfund Site, Milford, New Hampshire, 2011

By Philip T. Harte

Open-File Report 2012-1079 


\section{U.S. Department of the Interior \\ KEN SALAZAR, Secretary}

\section{U.S. Geological Survey \\ Marcia K. McNutt, Director}

U.S. Geological Survey, Reston, Virginia: 2012

For more information on the USGS-the Federal source for science about the Earth, its natural and living resources, natural hazards, and the environment-visit http://www.usgs.gov or call 1-888-ASK-USGS

For an overview of USGS information products, including maps, imagery, and publications, visit $h$ ttp://www.usgs.gov/pubprod

To order this and other USGS information products, visit $h$ ttp://store.usgs.gov

Suggested citation:

Harte, P.T., 2012, Evaluation of modeling for groundwater flow and tetrachloroethylene transport in the MilfordSouhegan glacial-drift aquifer at the Savage Municipal Well Superfund site, Milford, New Hampshire, 2011: U.S. Geological Survey Open-File Report 2012-1079, 29 p., at http://pubs.usgs.gov/of/2012/1079.

Any use of trade, product, or firm names is for descriptive purposes only and does not imply endorsement by the U.S. Government.

Although this report is in the public domain, permission must be secured from the individual copyright owners to reproduce any copyrighted material contained within this report. 


\section{Contents}

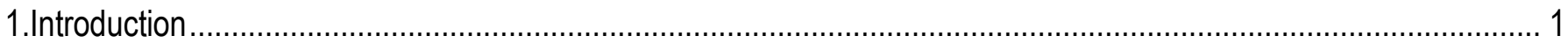

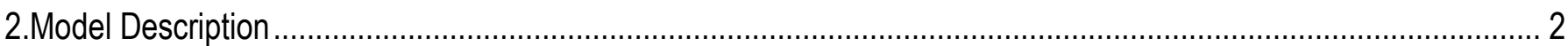

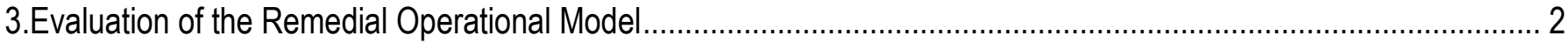

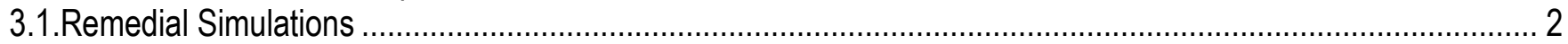

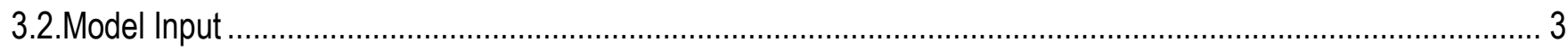

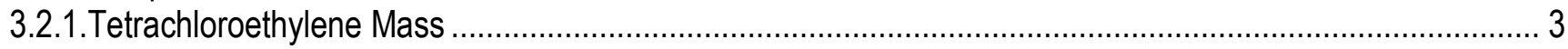

3.2.2.Aquifer and Transport Properties ………………………...................................................... 4

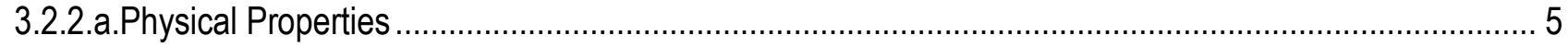

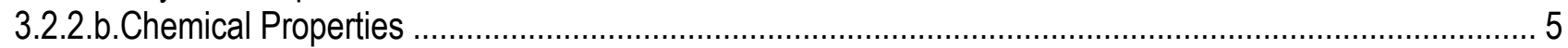

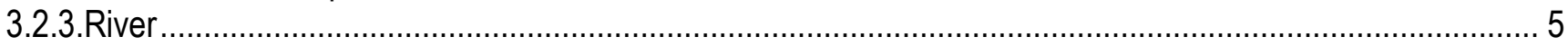

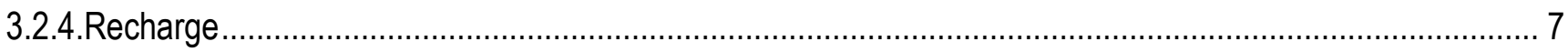

3.2.5. Well Extraction and Other Stresses....................................................................................

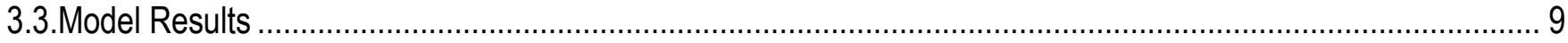

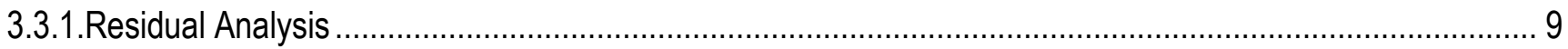

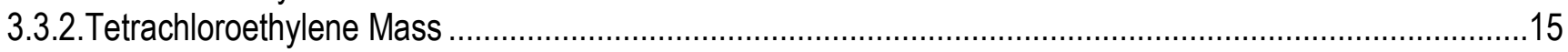

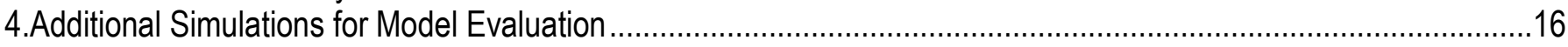

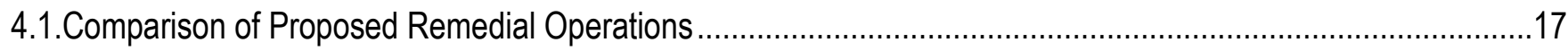

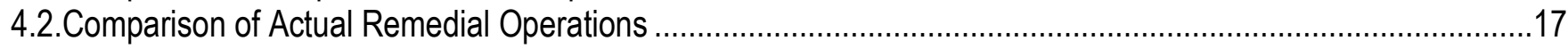

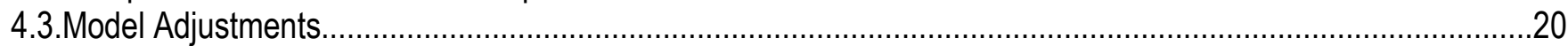

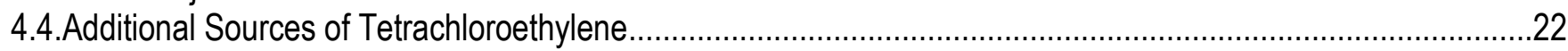

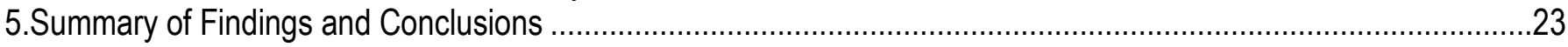

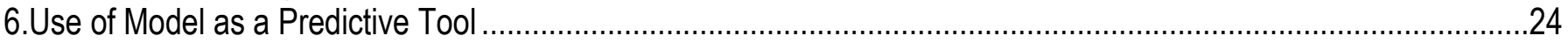

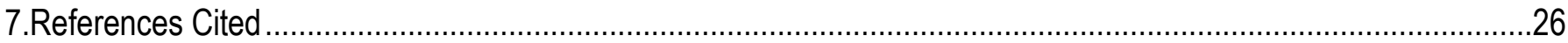

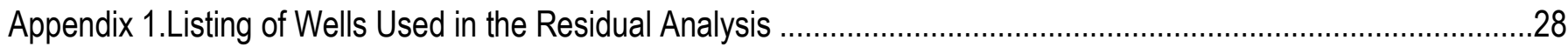

\section{Figures}

1. Location map of monitoring wells used in residual analysis and other selected features at the Savage Superfund site in Milford, New Hampshire

2. Hydrograph showing available streamflow data from the Souhegan River approximately 400 feet upstream of Operational Unit 1

3. Graphs showing model residuals for tetrachloroethylene concentrations from the remedial operational model and observed concentrations in December 2007

4. Graphs showing model residuals for tetrachloroethylene concentrations from the remedial operational model and observed concentrations in December 2010 .

5. Map showing model residuals for tetrachloroethylene concentrations in 2010 for layer 1 and 2 of the remedial operational model.

6. Map showing model residuals for tetrachloroethylene concentrations in 2010 for layer 3 of the remedial operational model.

7. Map showing model residuals for tetrachloroethylene concentrations in 2010 for layers 4 and 5 of the remedial operational model.

8. Graph showing tetrachloroethylene mass

9. Map showing remedial operational model-computed tetrachloroethylene (PCE) concentrations showing elevated PCE by the operational unit 1 barrier.

10. Chart showing model residual tetrachloroethylene (PCE) concentrations and observed PCE concentrations residuals in December 2010 for the simulation presented in table 8 
11. Graph of model-computed tetrachloroethylene (PCE) concentrations (base model) and observed PCE concentrations for PW-14 cluster wells

12. Graph of model-computed tetrachloroethylene (PCE) concentrations (base model) showing maximum PCE concentrations in OU2 under current remedial operation with a high retardation factor in layer 5

\section{Tables}

1. Tetrachloroethylene mass from model simulations

2. Corrected approximate flow rates for wells in the Milford-Souhegan glacial-drift aquifer at the Savage Superfund site in Milford, New Hampshire

3. Statistical summary of residual tetrachloroethylene concentrations for simulations using the remedial operational model based on 2007, 2008, 2009, and 2010 data

4. Statistical summary of model-computed tetrachloroethylene concentrations at monitoring wells in operational unit 2 (OU2) from a simulation comparison of actual and proposed OU2 remedy operations using the remedial operational model and base model with a comparison to 2010 observations

5. Volumetric budgets from models (remedial operational model and base model) for December 2009 .

6. Statistical summary of model-computed tetrachloroethylene concentrations at monitoring wells in operational unit 2 (OU2) from a simulation of actual OU2 remedial operations using the remedial operational model and base model with a comparison to 2010 observations

7. Statistical summary of model-computed tetrachloroethylene concentrations at monitoring wells in operational unit 2 (OU2) from a simulation of actual OU2 remedy operations (remedial operational and base models) and adjustment of retardation factor for layer 5 (base model) with a comparison to 2010 observations.

8. Statistical summary of model-computed tetrachloroethylene concentrations at monitoring wells in operational unit 2 (OU2) from a simulation of actual OU2 remedy operations (remedial operational and base models) and adjustment of starting mass ( 36 percent increase) for layer 5 (base model) with a comparison to 2010 observations 


\section{Conversion Factors and Datum}

Inch/Pound to SI

\begin{tabular}{|c|c|c|}
\hline Multiply & By & To obtain \\
\hline \multicolumn{3}{|c|}{ Length } \\
\hline inch (in.) & 2.54 & centimeter $(\mathrm{cm})$ \\
\hline foot $(\mathrm{ft})$ & 0.3048 & meter $(\mathrm{m})$ \\
\hline \multicolumn{3}{|c|}{ Hydraulic conductivity } \\
\hline \multicolumn{3}{|c|}{ Mass } \\
\hline kilogram (kg) & 2.205 & pound avoirdupois (lb) \\
\hline megagram $(\mathrm{Mg})$ & 1.102 & ton, short $(2,000 \mathrm{lb})$ \\
\hline
\end{tabular}

Vertical coordinate information is referenced to the North American Vertical Datum of 1988 (NAVD 88).

Horizontal coordinate information is referenced to the North American Datum of 1983 (NAD 83).

\section{Abbreviations and Acronyms}

BM
CHFB
MOC3D
MODFLOW
MODFLOW-GWT
MSGD
MT3D99
RDI
ROM
OU
PCE
USEPA
USGS
VMS

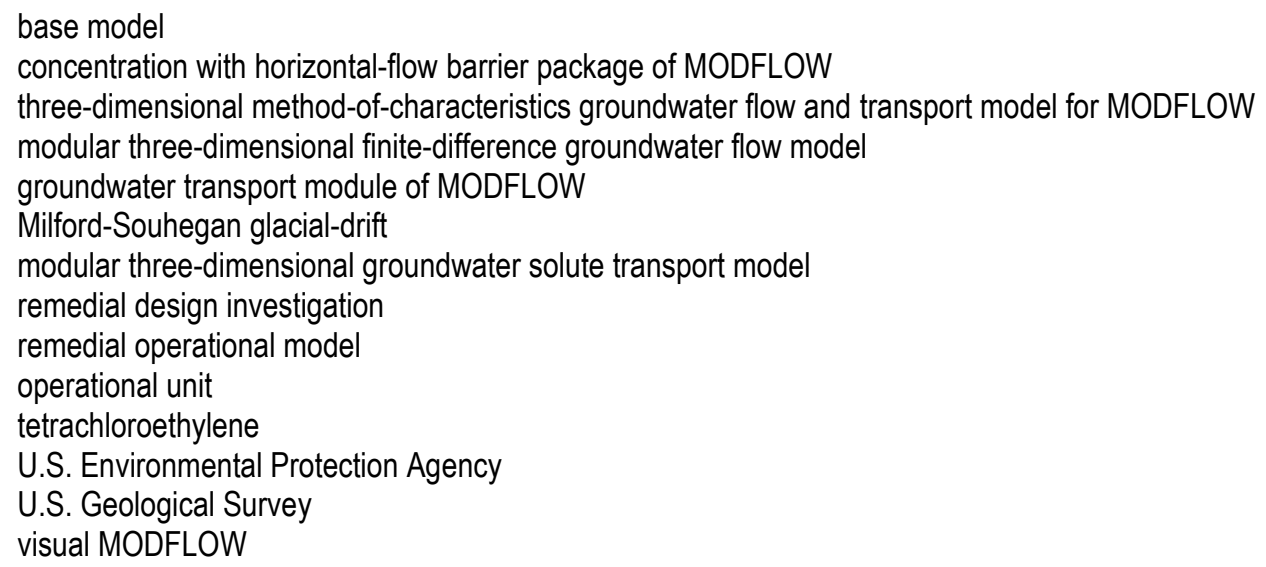




\title{
Evaluation of Modeling for Groundwater Flow and Tetrachloroethylene Transport in the Milford-Souhegan Glacial-Drift Aquifer at the Savage Municipal Well Superfund Site, Milford, New Hampshire, 2011
}

\author{
By Philip T. Harte
}

\section{Introduction}

Groundwater flow and transport modeling of the Savage Municipal Well Superfund (Savage Superfund) site was used to design the operable unit $1^{1}$ (OU1) and operable unit $2^{2}$ (OU2) remedial systems for treating the tetrachloroethylene (PCE) plume in the glacial sand and gravel deposits and underlying basal till, hereafter termed the Milford-Souhegan glacial-drift (MSGD) aquifer (Harte, 2004; Harte, 2006). Operable units define areas of contaminant concern within the Savage Superfund site. A detailed description of OU1 can be found in Harte (2006). Currently (2012), overall performance of the remedial system is being tracked through numerical modeling of groundwater flow and solute transport of PCE by comparing temporal trends in model-computed and observed PCE concentrations and mass (Gradient Corp., 2009). Understanding how well the model results compare to observed PCE trends is important to 1) predict PCE remedial timeframes, 2) understand flow and transport properties of the MSGD aquifer, 3) assess model performance, and 4) gauge the relative efficiency of the remedial system. All of these components are useful indicators in the determination of whether the remedy is protective of public health, safety, and the environment.

The U.S. Environmental Protection Agency (USEPA) conducts 5-year reviews of all remedial actions as part of the Comprehensive Environmental Response, Compensation, and Liability Act (CERCLA; USEPA, 2001). The purpose of the 5-year review, as described in USEPA document 540R-01-007 (USEPA, 2001), is to "evaluate the implementation and performance of a remedy in order to determine if the remedy is or will be protective of human health and the environment." USEPA document 540-R-01-007 also states that evaluation of the remedy and determination of protectiveness should be based on and sufficiently supported by data and observations.

The U.S. Geological Survey and the New Hampshire Department of Environmental Services entered into a cooperative agreement to assist in the evaluation of remedy simulations of the MSGD aquifer that are being performed by various parties to track the remedial progress of the PCE plume. This report summarizes findings from this evaluation. Topics covered include description of groundwater flow and transport models used in the study of the Savage Superfund site (section 2), evaluation of models and their results (section 3), testing of several new simulations (section 4), an assessment of the representation of models to simulate field conditions (section 5), and an assessment of models as a tool in remedial operational decision making (section 6).

\footnotetext{
${ }^{1}$ OU1 designates the primary source area of the Savage Municipal Well Superfund site.
}

${ }^{2} \mathrm{OU} 2$ designates the extended plume area of the Savage Municipal Well Superfund site. 


\section{Model Description}

For the purposes of this report, the term "model" refers to "the numerical three-dimensional groundwater flow and solute transport model of the MSGD aquifer." The model is a five-layer representation of the MSGD aquifer; the bedrock is not explicitly simulated. Model layers are vertical divisions or discretized sections of the aquifer into approximately 5-20 feet thick slices. The original model documented in Harte (2004) and the USEPA's remedial design modeling report (USEPA, 2002) is referred to as the base model (BM) in this document, and the model described in the 2002 RDI report and modified in subsequent annual reports (Gradient Corp., 2009) is referred to as the remedial operational model (ROM). The ROM was used to simulate actual remedy operations, including the actual extraction and injection well pumping rates of OU2.

The ROM (and by extension the BM) solves the groundwater flow and solute transport equation for single chemical species (for the purposes of this study, PCE). Output from model simulations is compared with observed PCE concentrations to evaluate model performance. The ROM was originally calibrated in 2001 and has not been recalibrated, although annual comparisons are made between model-computed and observed PCE concentrations from a network of OU2 monitoring wells (Gradient Corp., 2009). Several modifications to the input of the ROM and remedy simulations (Gradient Corp., 2009) have not been reviewed prior to the 5-year review by the USEPA.

The basic structure of the ROM, cell discretization, model grid, and model layering have been unaltered from the BM, which was patterned after the construction of the original flow model of the western MSGD aquifer (Harte and others, 1999). However, cell thickness, hydraulic conductivities ${ }^{3}$, and other features such as PCE plume mass have been adjusted over time based on new data and model calibration (Gradient Corp., 2002).

The initial conditions for the ROM and BM differ. For a discussion of initial conditions for the ROM see section 3.1. For the BM, the initial conditions represent groundwater flow and transport at the start of the OU1 remedy (1999), after the completion of the barrier wall. The BM simulates transient flow and transport from 1999.

\section{Evaluation of the Remedial Operational Model}

Discussion in this section includes an evaluation of the ROM input and comparison to the BM. This section also covers an analysis of model output results.

Model input and selected model output of the ROM were checked by examining ASCII model input files, Visual MODFLOW (VMS) files provided by Gradient Corp. (Neal Grasso, Gradient Corp., December 23, 2010, written commun.), and model output as reported in annual reports and examined in model output files. Although VMS files are a graphical representation of model input and output and allow for a quicker inspection of the model, limited use of this process was allowable because models for different time periods were constructed using different versions of the VMS software (either 4.3 or 4.4).

\subsection{Remedial Simulations}

The ROM uses average annual recharge and river conditions to simulate hydrologic conditions (post 2001) in the MSGD aquifer (Neal Grasso, Gradient Corp., December 23, 2010, written commun.) based on hydrologic data from 1994-95 as described by Harte and others (1999). The OU2 remedy extraction and injection rates (well pumpage, which started in 2005), were adjusted over time based on actual usage (Gradient Corp., 2009). OU1 remedy operations (extraction and injection) and extraction

\footnotetext{
${ }^{3}$ Groundwater storage is not simulated in the ROM.
} 
from the State fish hatchery and other active extraction wells (excluding OU2 remedy wells) in the MSGD aquifer have not been adjusted in the ROM to reflect actual changes in extraction and injection rates over time. The OU1 remedy began in 1999.

Model simulations are extended from previous simulations (post 2001) in monthly time increments in the ROM (Neal Grasso, Gradient Corp., December 23, 2010, written commun.). The model output of PCE from the previous simulations is used as the input for the starting PCE concentrations of the next simulation. Groundwater flow is assumed to be at steady state and initial, time representative, heads are not required for a solution.

All ROM simulations are performed using MODFLOW-96 software for groundwater flow (Harbaugh and McDonald, 1996), MT3D99 modeling software for solute transport (Zheng, 1990; Zheng and Wang, 1999), and the preprocessor and postprocessor built into VMS (version 4.3 or 4.4; Neal Grasso, Gradient Corp., December 23, 2010, written commun.). The BM uses a combination of software including MODFLOW-96, MOC v.3.5 (Konikow and others, 1996), MODFLOW-2000 (Harbaugh and others, 2000) and MODFLOW-GWT (U.S. Geological Survey, 2011).

Transport with MT3D99 does not require a uniform grid cell size and transport was simulated for the entire grid (Neal Grasso, Gradient Corp., December 23, 2010, written commun.). Transport with MOCv.3.5 or MODFLOW-GWT uses a subgrid approach to avoid transport in nonuniform grid cell sizes to help with numerical solutions with the standard package of MODFLOW-GWT. For the BM, PCE transport was simulated using subgrids from row 23 to 140 (nonuniform size cells) or row 53 to 140 (uniform size cells) of the model utilizing two different solvers for transport. Simulations that used a subgrid with nonuniform size cells utilized an enhanced solution of MODFLOW-GWT developed by Heberton and others (2000).

\subsection{Model Input}

Model input can be divided into several categories, including initial PCE mass (concentrations of the plume), physical properties of the MSGD aquifer including hydraulic conductivity, and chemical properties, such as retardation of PCE. Other important model input factors include specified flows (groundwater recharge, well extractions) and physical components of the remedial system, such as the barrier wall.

\subsubsection{Tetrachloroethylene Mass}

Initial PCE concentrations are a critical component in the formulation of a transport model. PCE mass was defined differently for the ROM and BM models. PCE concentrations are assigned to model cells to represent the PCE plume based on an interpolation process from observed PCE concentrations. Inadequate coverage of wells, inaccurate formulation of the spatial distribution of PCE, and inappropriate interpolation schemes can lead to underestimation or overestimation of the model assigned PCE mass relative to the true PCE mass. An underestimated initial PCE mass will underpredict PCE concentration over time and produce unrealistically high attenuation rates for the plume. Conversely, an overestimated initial PCE mass will overpredict PCE concentrations over time and produce low attenuation rates.

Initial PCE concentrations were examined for the ROM to determine differences in PCE mass between different simulations. The post calibration simulation period began in 2001. Simulations after 2001 use the previous simulation as an initial solute concentration (Neal Grasso, Gradient Corp., December 23, 2010, written commun). For the 2001 simulation period, the ROM used the initial modelcomputed PCE concentration from the model calibration (Andy Bittner, Gradient Corp. , June 23, 2011, written commun.). Model PCE mass from 2001 had a total mass (dissolved and sorbed) of 4,226 kilograms (kg; table 1). The OU2 area by itself had a total (dissolved and sorbed) PCE mass of 3,660 
$\mathrm{kg}$. The latter constitutes the PCE mass values shown in figure 3.18 of Gradient reports $(2008,2009)$ (fig. 8).

Table 1. Tetrachloroethylene mass from model simulations.

[Mass is estimated from observed tetrachloroethylene (PCE) concentrations and estimated sorbed phase of PCE. The base model (BM) is from USEPA (2002) and Harte (2004); the remedial operational model (ROM) is from Gradient (2009). kg, kilogram; NA, not available; OU1, operational unit 1; OU2, operational unit 2]

\begin{tabular}{|c|c|c|c|c|c|c|}
\hline \multirow[b]{2}{*}{ Model } & \multirow[b]{2}{*}{$\begin{array}{l}\text { Simulated } \\
\text { year }\end{array}$} & \multirow{2}{*}{$\begin{array}{l}\text { OU2 total } \\
\text { (dissolved } \\
\text { and sorbed) } \\
\text { PCE }(\mathrm{kg})\end{array}$} & \multicolumn{3}{|c|}{ Combined OU1 and OU2 } & \multirow[b]{2}{*}{ Comments } \\
\hline & & & $\begin{array}{l}\text { Dissolved } \\
\text { PCE }(k g)\end{array}$ & $\begin{array}{c}\text { Sorbed PCE } \\
(\mathrm{kg})\end{array}$ & $\begin{array}{l}\text { Total PCE } \\
(\mathrm{kg})\end{array}$ & \\
\hline Remedial operational & 1998 & NA & NA & NA & 5,657 & OU1 constant source cells added. \\
\hline Remedial operational & 2001 & 3,660 & NA & NA & 4,226 & $\begin{array}{l}\text { Starting mass for remedial simulations; } \\
\text { estimated from model. }\end{array}$ \\
\hline
\end{tabular}

PCE mass from 2001 was computed from simulations that began in 1995 and continued from 1995 to 1998 (pre-barrier wall) and from 1998 through 2001 (post-barrier wall). During the 1995 to 1998 period, additional mass was added inside the barrier to simulate transfer of PCE to dissolved phases from a dense nonaqueous phase liquid (DNAPL) or residual source (Gradient Corp., 2002). The amount of mass added was not known to the author but should be reflected in the total mass of 4,226 kg (table 1). The RDI report indicated that, during calibration with the 2001 PCE dataset, it was necessary to increase the starting PCE mass in selected parts of the aquifer (Gradient Corp., 2002).

In contrast, simulations with the BM that began in 1998 as described in Harte (2004) had a starting mass of $2,700 \mathrm{~kg}(1,200 \mathrm{~kg}$ dissolved and $1,500 \mathrm{~kg}$ sorbed $)$. The initial mass for the 1998 model simulations was computed by adjusting the 1995 PCE plume interpolated from a comprehensive vertical profiling program in 1995 based on the computation of spatially derived difference ratios, determined from the ratio of PCE concentrations at commonly sampled wells between 1995 and 1998 (Harte, 2004). Essentially, the difference ratios are used to adjust PCE concentrations derived from vertical profiling from values in 1995 to values in 1998. This method of computing initial PCE concentrations to the model allowed for the use of the profiling data to interpolate PCE concentrations and create an initial PCE plume for simulation starting in 1998 after the installation of the OU1 ${ }^{4}$ barrier. By starting simulations in 1998, no PCE source terms are necessary because it is assumed that the barrier encapsulates residual pockets of DNAPL. PCE concentration differences inside the barrier from the specification of the PCE source term has less of an effect on PCE transport across the barrier in the early times of remediation (less than 6 years) than other transport factors.

\subsubsection{Aquifer and Transport Properties}

The physical properties of the aquifer affect flow and advective transport of PCE. The chemical properties of the aquifer also affect the transport of PCE as well as the amount of PCE mass stored on sediments of the aquifer.

\footnotetext{
${ }^{4}$ The barrier is a low permeability slurry wall that encircles the highest concentrations of PCE in OU1. It penetrates the full thickness of the sand and gravel deposits, partially penetrates the underlying discontinuous basal till, and in some locations it sits directly on top of the bedrock.
} 


\subsection{2.a. Physical Properties}

Groundwater flow is computed in the ROM with MODFLOW-96 and the Block Centered Flow (BCF) module (Harbaugh and McDonald, 1996). Hydraulic conductivity, porosity, and model layer thickness are specified for each model cell. The BM also uses similar modeling options except that aquifer storage is simulated for transient changes.

Hydraulic conductivity is uniform within zones of the aquifer and varies by layer for both the ROM and BM models (Harte and others, 1999; Gradient Corp., 2002, figs. 3.2-3.6). The MSGD aquifer is simulated as horizontally isotropic but vertically anisotropic; vertical anisotropy varies from one-half to one-tenth of the horizontal hydraulic conductivity.

The distribution of horizontal hydraulic conductivity in the ROM is similar to that of the BM with one exception. The high horizontal hydraulic conductivity zone [147 feet per day (ft/d); figs. 3-5; Gradient Corp., 2002] in ROM for layer 4 differs from that specified in the BM. In the BM, the horizontal hydraulic conductivity was reduced from $147 \mathrm{ft} / \mathrm{d}$ to $60 \mathrm{ft} / \mathrm{d}$ during simulations in 2006 to better approximate hydraulic conductivities of the stratified-drift deposits at similar elevations in model layer 4.

The barrier wall is simulated in the ROM and the BM using the hydraulic barrier package of MODFLOW (Hsieh and Freckleton, 1993). Groundwater flow is essentially restricted by adjusting the intercell hydraulic conductivity. Groundwater transport across the barrier is affected by the reduced rates of flow. However, unless a low rate of dispersivity was assigned to the barrier and the transport equation was reformulated, unrealistically high rates of dispersion across the barrier occurred during simulations (Harte and others, 2006). Harte (2006) showed that it was necessary to increase the flow across the barrier by increasing the hydraulic conductivity of the barrier for layer 5 in the BM to offset increased extraction inside the barrier during a simulated period from 2003 to 2006. Therefore, the hydraulic conductivity of the barrier in layer 5 of the ROM differs from the increased hydraulic conductivity specified in the BM.

Dispersion of a solute from the average solute flow is simulated using the dispersivity coefficient and equation. In the ROM, dispersivity was set to be $54 \mathrm{ft}$ in the longitudinal direction, 0.54 $\mathrm{ft}$ in the transverse, and $0.54 \mathrm{ft}$ in the vertical. In contrast, the BM used the same longitudinal dispersivity but transverse and vertical dispersivities of $12 \mathrm{ft}$ and $1.2 \mathrm{ft}$, respectively, to account for dispersive effects from transient conditions in the aquifer.

\subsection{2.b. Chemical Properties}

Dissolved and sorbed PCE are simulated assuming a linear isotherm relation and is controlled by the use of a retardation factor. Retardation factors for the ROM were based on work done in the BM (Harte, 2004); the retardation factor varies between 2 and 2.5 depending on the model layer.

PCE biodegradation is not simulated in the models. However, the BM simulates a small rate of volatilization of PCE that results in less than 0.01 percent attenuation of the PCE plume (Harte, 2004).

\subsubsection{River}

The ROM uses the river package of MODFLOW-96, which simulates the river as a specifiedhead boundary. River stage, river dimensions, and riverbed hydraulic conductance have not been significantly adjusted since earlier calibration work by Harte and others (1999) except for areas near the New Hampshire State fish hatchery wells.

The amount of flow in a discharge ditch (fig. 1) draining industrial wastewater (located along the south part of the plume) has not been measured since extraction from the industrial well (fig. 1; MI-88) has been reduced and flow discharges to the ditch altered. This could cause problems with accurately 
simulating groundwater flow in areas near the ditch because the ditch can serve as a recharge source to shallow parts of the MSGD aquifer (Harte and others, 1999).

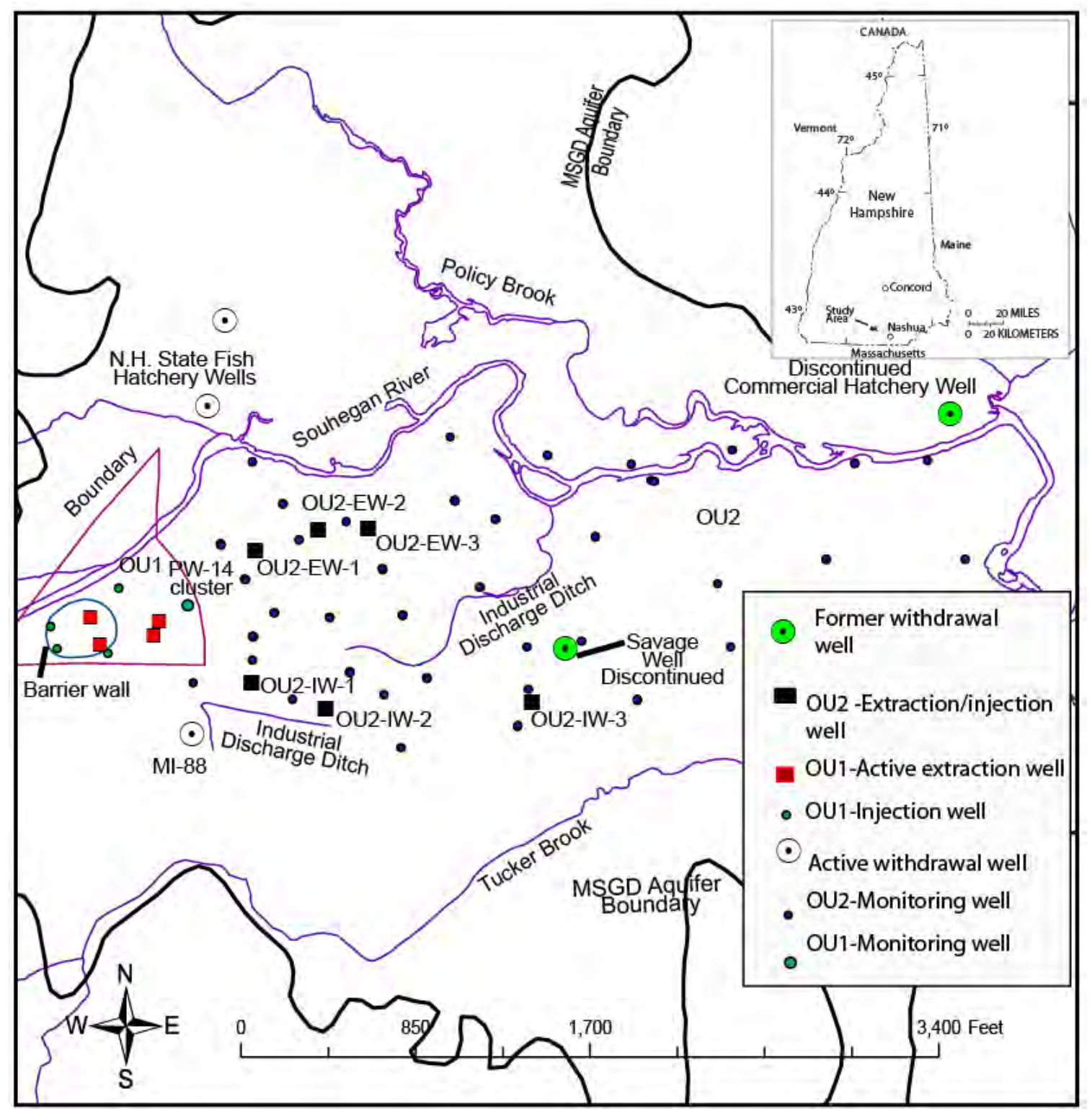

Figure 1. Location map of monitoring wells used in residual analysis (based on Gradient Corp., 2009, table 3-3) and other selected features at the Savage Superfund site in Milford, New Hampshire. EW, extraction well; IW, injection well; MSGD, Milford-Souhegan glacial-drift; OU1, operational unit 1; OU2, operational unit 2; PW, monitoring well.

River stage was kept at long-term steady state levels in model input (Neal Grasso, Gradient Corp., December 23, 2010, written commun.). Trends in streamflow and river stage have not been investigated to identify whether model river stage should be adjusted over time. 


\subsubsection{Recharge}

Recharge occurs from infiltration of precipitation and overland runoff from adjacent upland areas to the MSGD aquifer. Rates of recharge were initially developed in Harte and others (1999) for average annual and monthly periods. However, rates of recharge in the ROM have not been adjusted to account for seasonal or annual differences in precipitation since this initial work.

Recharge rates to the MSGD aquifer vary by season and annually. Summer and fall low flows, which can represent a large proportion of groundwater discharge (discharge roughly equivalent to available groundwater recharge), varied by an order of magnitude [ 2 cubic feet per second $\left(\mathrm{ft}^{3} / \mathrm{s}\right.$ ) to 20 $\mathrm{ft}^{3} / \mathrm{s}$ ] based on reported streamflow data from the USGS gage near OU1 (fig. 2). The anticipated variation in recharge, as indicated by streamflows, will affect groundwater flow and transport as well as capture of contaminants by remedial extraction wells. If the flow and transport model does not account for this variation, then the simulated transport will be affected and the validation of model performance will be complicated.

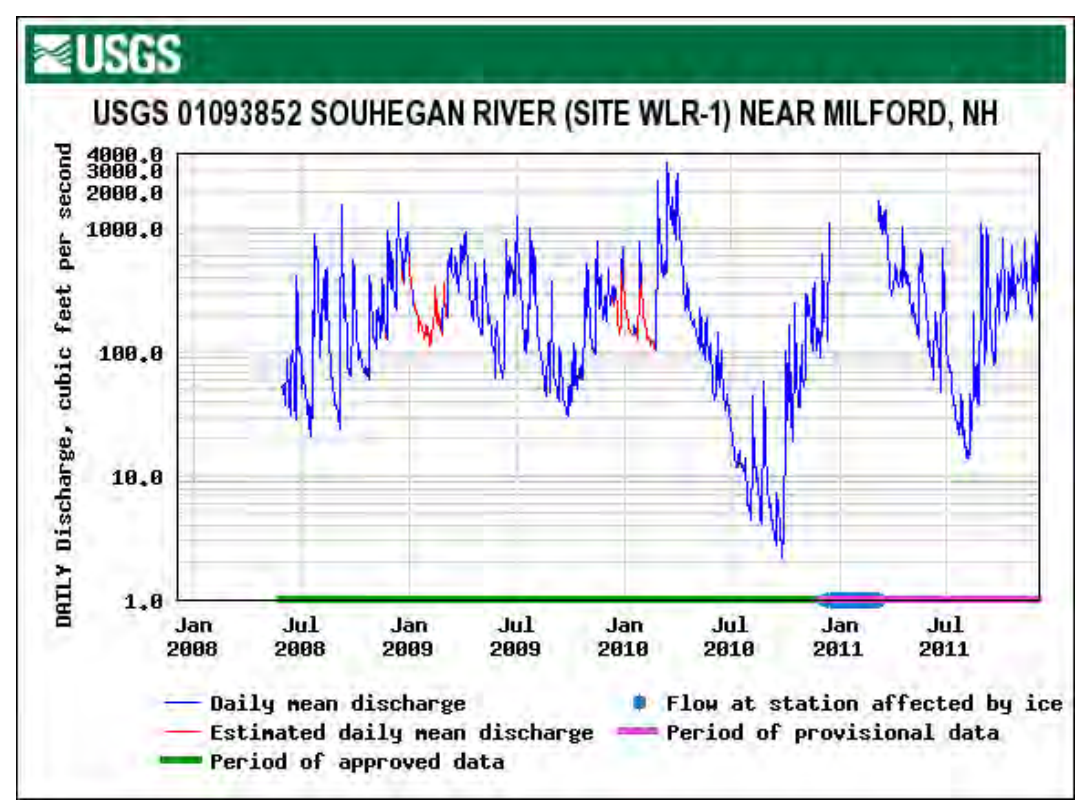

Figure 2. Hydrograph showing available streamflow data from the Souhegan River approximately 400 feet upstream of Operational Unit 1. Summer and fall low flows varied by an order of magnitude reflecting available recharge to groundwater. [Provisional data from January 2011 to July 2011 have not been reviewed or edited and may be subject to significant change; provisional data are not citable until reviewed and approved by the U.S. Geological Survey.]

\subsubsection{Well Extraction and Other Stresses}

Well extraction and injections have changed significantly with time. Rates of extraction and injection from the OU2 remedial system have been adjusted over time in the ROM to reflect field conditions. However, rates of extraction and injection from the OU1 remedial system and rates of extraction from the State fish hatchery wells, an important area of large extraction, have not been adjusted in the ROM to reflect field conditions (Neal Grasso, Gradient Corp., December 23, 2010, written commun). Table 2 contains a corrected summary of extraction and injection rates (in cubic-footper-second $\left.\left(\mathrm{ft}^{3} / \mathrm{s}\right)\right)$ that better reflect stresses on the aquifer. 
Table 2. Corrected approximate flow rates for wells in the Milford-Souhegan glacial-drift aquifer at the Savage Superfund site in Milford, New Hampshire.

[Continuous time series data not available ; Negative numbers indicate withdrawals; Red numbers are data corrected from Gradient Corp. (2009,) and based on model files by the U.S. Geological Survey; MI-88 rates are based on Gradient Corp. (2009) data; OU2 data are from Gradient Corp. (2009); OU1 data are from monthly pumpage reports and OU1 annual reports (Weston, Inc., 2009); Rates for wells FH-4,FH-5, and OU1 wells are corrected and differ from rates in the remedial operational model; ND means no data]

\begin{tabular}{|c|c|c|c|c|c|c|c|c|c|c|c|c|c|c|c|c|c|c|}
\hline \multirow[b]{2}{*}{ Area } & \multirow[b]{2}{*}{ Name } & \multicolumn{3}{|c|}{ Model locations } & \multicolumn{14}{|c|}{ Approximate rates of flow, in cubic feet per second } \\
\hline & & Layer & Row & Col & 1999 & 2000 & 2001 & 2002 & $\begin{array}{l}\text { Early } \\
2003\end{array}$ & 2004 & $\begin{array}{c}2004- \\
\text { summer } 2005\end{array}$ & $\begin{array}{l}\text { Fall } \\
2005\end{array}$ & 2006 & 2007 & $\begin{array}{c}\text { Spring } \\
2008\end{array}$ & $\begin{array}{l}\text { Dec. } \\
2008\end{array}$ & 2009 & 2010 \\
\hline OU2 & MI-88 & $2-3$ & 128 & 39 & -0.38 & $\begin{array}{l}-0.38 \\
\end{array}$ & -0.38 & -0.002 & -0.002 & -0.002 & $\begin{array}{l}-0.002 \\
\end{array}$ & $\begin{array}{l}-0.002 \\
\end{array}$ & $\begin{array}{l}-0.002 \\
\end{array}$ & -0.002 & -0.002 & -0.002 & -0.002 & -0.002 \\
\hline State & $\mathrm{FH}-4$ & $2-3$ & 40 & 55 & -2.578 & -2.578 & -2.578 & -2.578 & -2.578 & -2.62 & -2.62 & -2.62 & -2.62 & -2.62 & -2.62 & ND & -2.42 & -2.42 \\
\hline State & FH-5 & 3 & 28 & 59 & -1.63 & -1.63 & -1.4 & -1.3 & -1.1 & -1.1 & -1.1 & -1.1 & -1.1 & -1.1 & -1.1 & -1.1 & -1.36 & ND \\
\hline OU2 & OU2-EW 1 & $2-4$ & 73 & 60 & 0 & 0 & 0 & 0 & 0 & 0 & 0 & start & ND & -0.446 & ND & -0.423 & -0.115 & -0.437 \\
\hline OU2 & OU2-EW 2 & $2-4$ & 70 & 67 & 0 & 0 & 0 & 0 & 0 & 0 & 0 & start & ND & -0.265 & ND & -0.301 & -0.289 & -0.278 \\
\hline OU2 & OU2-EW3 & $2-3$ & 72 & 74 & 0 & 0 & 0 & 0 & 0 & 0 & 0 & start & ND & -0.208 & ND & -0.223 & -0.22 & -0.206 \\
\hline OU2 & OU2-IW1 & $2-5$ & 111 & 53 & 0 & 0 & 0 & 0 & 0 & 0 & 0 & start & ND & 0.223 & ND & 0.223 & 0.171 & 0.223 \\
\hline OU2 & OU2-IW2 & $3-5$ & 122 & 62 & 0 & 0 & 0 & 0 & 0 & 0 & 0 & start & ND & 0.223 & ND & 0.256 & 0.189 & 0.274 \\
\hline OU1 & RW3 & $1-2$ & 93 & 34 & 0 & 0 & 0 & 0 & 0.038 & 0 & some flow & some flow & some flow & 0 & 0 & 0 & 0 & 0 \\
\hline OU1 & RW-2 & $1-2$ & 89 & 27 & 0.01 & 0 & some flow & 0 & 0 & 0 & 0 & 0 & some flow & 0 & 0 & 0 & 0 & 0 \\
\hline OU1 & EW2 & $3-4$ & 91 & 41 & -0.056 & -0.035 & -0.042 & -0.035 & -0.034 & -0.047 & -0.047 & $-6 \times 10^{-5}$ & -0.045 & -0.045 & 0 & 0 & 0 & -0.01 \\
\hline OU1 & EW1 & $4-5$ & 87 & 42 & -0.028 & -0.032 & -0.067 & -0.067 & -0.018 & -0.047 & -0.047 & $-2 \times 10^{-4}$ & 0 & 0 & 0 & 0 & 0 & trace flow \\
\hline OU1 & IW2 & $3-4$ & 82 & 32 & -0.008 & -0.034 & -0.027 & -0.058 & -0.069 & 0 & -0.047 & $-2 \times 10^{-4}$ & -0.069 & -0.069 & -0.032 & 0 & 0 & 0 \\
\hline OU1 & IW1 & $4-5$ & 90 & 33 & -0.022 & -0.03 & -0.03 & -0.025 & -0.069 & 0.068 & -0.145 & $-2 \times 10^{-4}$ & -0.069 & -0.069 & -0.085 & 0 & 0 & 0 \\
\hline OU1 & IW2A & 1 & 82 & 32 & 0 & 0 & 0 & 0 & 0 & 0 & 0 & 0 & 0 & 0 & 0 & -0.01 & -0.01 & -0.01 \\
\hline OU1 & IW1A & 1 & 90 & 33 & 0 & 0 & 0 & 0 & 0 & 0 & 0 & 0 & 0 & 0 & 0 & -0.045 & -0.045 & -0.028 \\
\hline
\end{tabular}


Several important discrepancies exist between actual reported rates and simulated rates in the ROM. Extraction rates of $-1.42 \mathrm{ft}^{3} / \mathrm{s}$ and $-2.57 \mathrm{ft}^{3} / \mathrm{s}$ were specified for State fish hatchery wells FH-5 and $\mathrm{FH}-4$. Actual reported rates vary from $-1.1 \mathrm{ft}^{3} / \mathrm{s}$ to $-1.63 \mathrm{ft}^{3} / \mathrm{s}$ for $\mathrm{FH}-5$ and $-2.42 \mathrm{ft}^{3} / \mathrm{s}$ and $-2.62 \mathrm{ft}^{3} / \mathrm{s}$ for FH-4 (table 2). FH-4 is adjacent to the Souhegan River near the edge of the PCE plume, and differences in extraction can cause northerly (increased extraction) or southerly (decreased extraction) shifting of the plume. Also, differences in extraction and injection data between actual and simulated rates in the ROM are large for OU1 remedial wells. In some cases, no actual extraction occurred yet extraction is simulated in the model. For example, OU1-EW1 actual extraction varied from $0 \mathrm{ft}^{3} / \mathrm{s}$ to $.046 \mathrm{ft}^{3} / \mathrm{s}$, whereas the simulated extraction was kept constant at $-0.0557 \mathrm{ft}^{3} / \mathrm{s}$. Uncertainty exists in the extraction rate specified for well MI-88 (industrial well) (table 2). Previous reporting indicated that the well was shut down in 2002. However, examination of well extraction rates used in the ROM show a small rate (table 2) of extraction (Neal Grasso, Gradient Corp., December 23, 2010, written commun). It is important to determine the amount of water use at well MI-88 and whether extracted water is discharged to the adjacent discharge ditch. Several ROM layer assignments, including OU1 well IW2 (correct simulated layers are 3-4) and OU2 remedy wells EW1, EW3, IW3 (table 2), could potentially be adjusted based on new data.

\subsection{Model Results}

Model output from several times was examined to evaluate ROM performance. Dates examined included December 2007, December 2008, January and December 2009, and December 2010. Typically, a description of model results includes an examination of models budgets (volumetric flow and solute transport budget), and a spatiotemporal analysis of the model-output solution. This section focuses on a diagnostic presentation of model results.

\subsubsection{Residual Analysis}

Model residual analysis can be used to assess model performance by comparing PCE concentrations computed from the model to observed PCE concentrations. Residual analysis was done for 2007, 2008, 2009, and through 2010 (earlier datasets were not available for review). The datasets that contain the ROM results and observed data were provided by Gradient Corp. (2008-09; table 3.3). The wells used in the residual analysis are listed in appendix 1. The locations of wells used in the residual analysis correspond to OU2 monitoring wells as shown in figure 1. Monitoring wells are not labeled in figure 1 but are labeled in subsequent maps of spatial PCE residuals. These wells (appendix 1) were used by Gradient Corp. (2009) for their model assessment purposes, which did not include OU1 wells.

Summary statistics for residual data from model simulations show a mean residual difference (model-computed minus observed) between 97 to 19 parts per billion (ppb) for all sampled wells over the 4 time periods (table 3); the mean difference appears to be getting smaller with time. A smaller residual difference with time suggests an improvement in model performance because model PCE concentrations better match observed PCE concentrations over time. This trend is also evident in sampled wells that are common to the four reported dates (table 3). 
Table 3. Statistical summary of residual tetrachloroethylene concentrations for simulations using the remedial operational model based on 2007, 2008, 2009, and 2010 data.

[All units in parts per billion. Data are from Gradient Corp. (2009). Wells are listed in appendix 1. RMSE, root mean square deviation; --, zero]

\begin{tabular}{|c|c|c|c|c|}
\hline & 2007 & 2008 & 2009 & 2010 \\
\hline \multicolumn{5}{|c|}{ All wells } \\
\hline Mean & 97 & 97 & 45 & 19 \\
\hline Minimum & -538 & -276 & -310 & -293 \\
\hline Maximum & 585 & 504 & 409 & 243 \\
\hline Median & 30 & 63 & 36 & 9 \\
\hline Standard deviation & 202 & 164 & 154 & 109 \\
\hline RMSE & 28 & 28 & 24 & 14 \\
\hline Count & 64 & 45 & 44 & 59 \\
\hline \multicolumn{5}{|c|}{ Common wells } \\
\hline Mean & 119 & 98 & 45 & 20 \\
\hline Minimum & -538 & -276 & -310 & -293 \\
\hline Maximum & 585 & 504 & 409 & 243 \\
\hline Median & 24 & 65 & 36 & 26 \\
\hline Standard deviation & 230 & 165 & 154 & 122 \\
\hline RMSE & -- & -- & 24 & -- \\
\hline Count & 44 & 44 & 44 & 44 \\
\hline
\end{tabular}

Graphical comparisons of ROM residual PCE by model layer as a function of observed concentrations in 2007 and 2010 are shown in figures 3 and 4 and suggest some bias in model performance. All graphed values (model residual PCE and observed concentrations) are based on reported data by Gradient Corp. (2009). These graphs can be used to identify trends in model performance and whether residual PCE from the models are biased for certain ranges in observed concentrations. Ideally, residual PCE would be evenly distributed about the line marked "Optimal Residual Distribution" and show no bias with concentration or layer. 


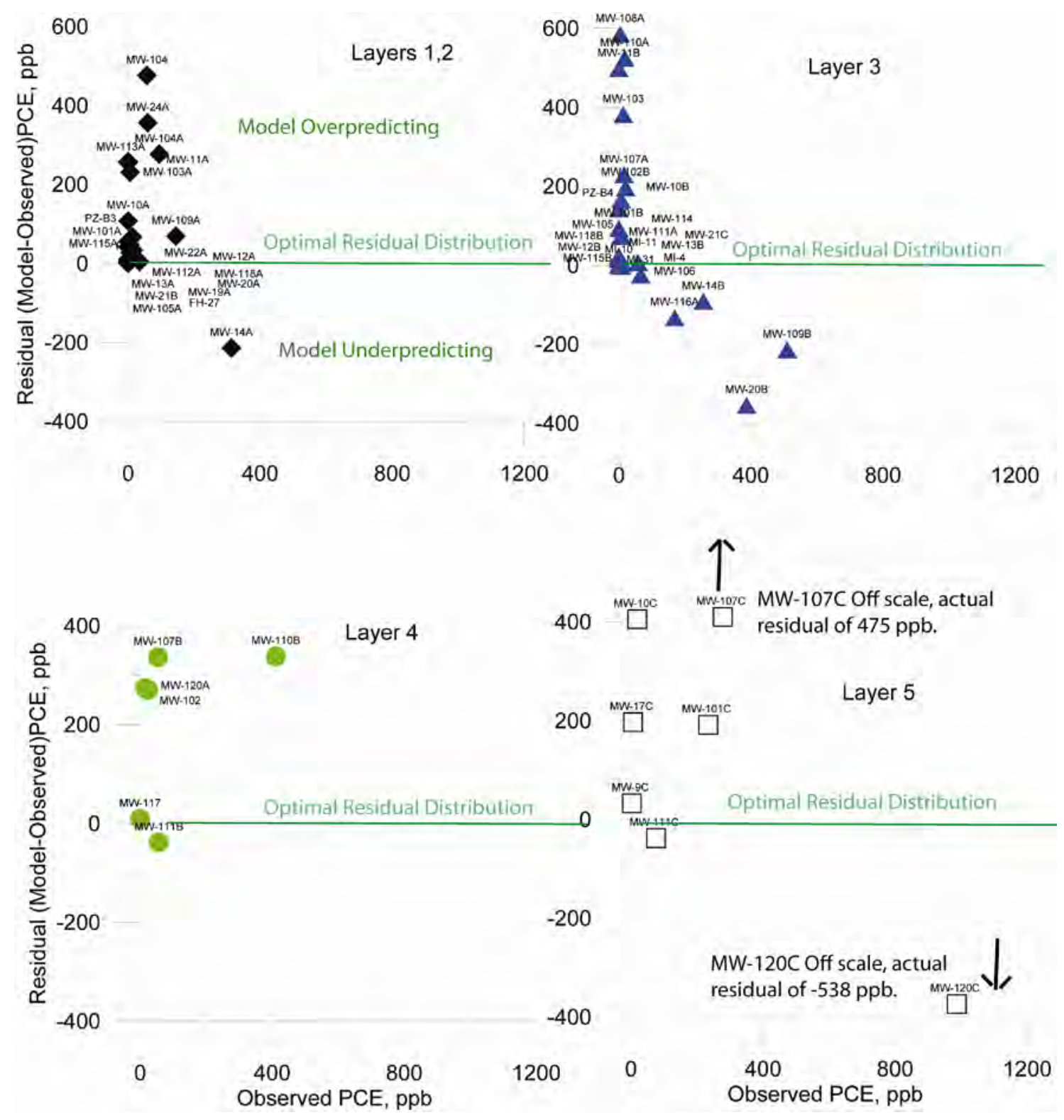

Figure 3. Graphs showing model residuals for tetrachloroethylene concentrations from the remedial operational model and observed concentrations in December 2007. Well coordinates are provided in appendix 1. 

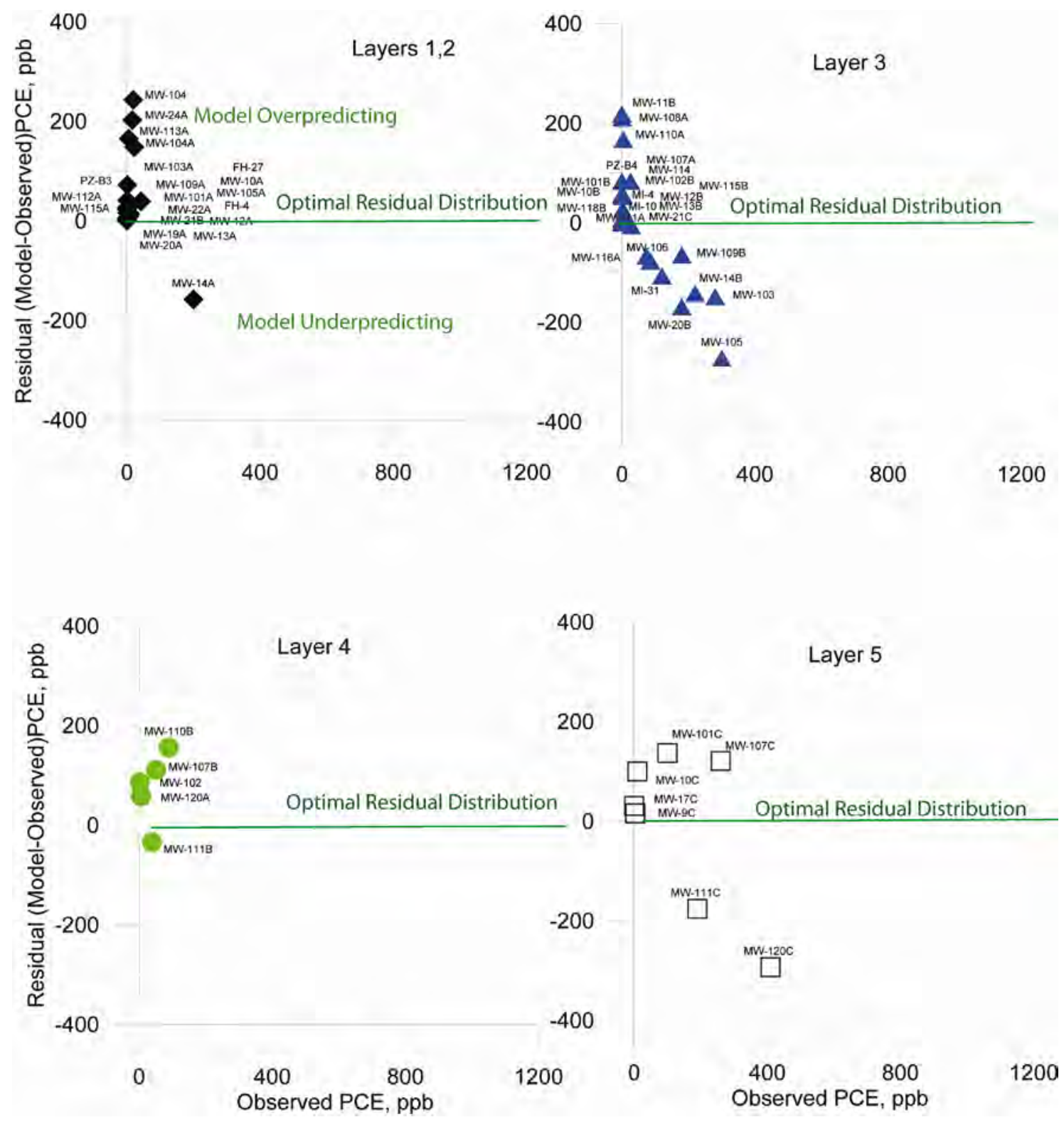

Figure 4. Graphs showing model residuals for tetrachloroethylene concentrations from the remedial operational model and observed concentrations in December 2010. Well coordinates are provided in appendix 1.

Results show that the ROM is overpredicting well concentrations (model-computed concentrations exceed observed concentrations) in areas of low $(<100 \mu \mathrm{g} / \mathrm{L})$ observed concentrations and underpredicting well concentrations in areas of high $(>100 \mu \mathrm{g} / \mathrm{L})$ observed concentrations in all model layers for 2007 and 2010. Viewed in this format, ROM performance appears to be less favorable than interpreted from gross statistics, indicating that the configuration and location of the model plume does not match the observed plume. Matching the observed plume with the simulated plume would improve the reliability of predictive remedial timeframes.

Spatial PCE residual maps for 2010 for layers 1 and 2 (combined), 3, and 4 and 5 (combined) show that the ROM is overpredicting concentrations near the extraction wells (OU2-EW1, OU2-EW2, and OU2-EW3) and underpredicting near the discharge ditch and to the east (figs. 5-7). The latter 
represents areas where injected groundwater near OU2-IW2 and OU2-IW3 were expected to accelerate flushing and transport of PCE in the MSGD aquifer and push PCE out (ultimately discharge PCE contaminated groundwater) to the Souhegan River. Field data indicate PCE is not being flushed out at the rate suggested in the model.

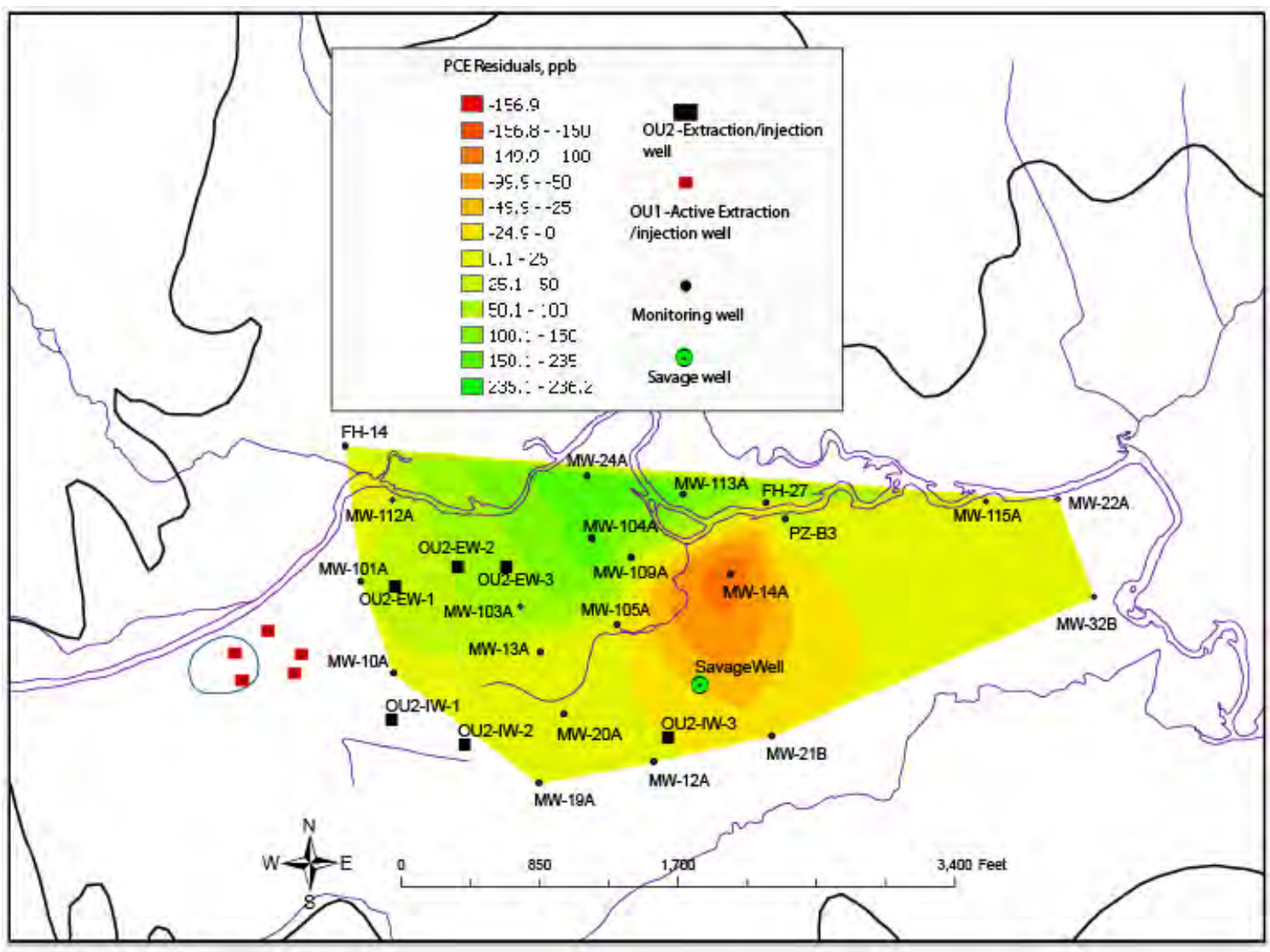

Figure 5. Map showing model residuals for tetrachloroethylene concentrations in 2010 for layer 1 and 2 of the remedial operational model. 


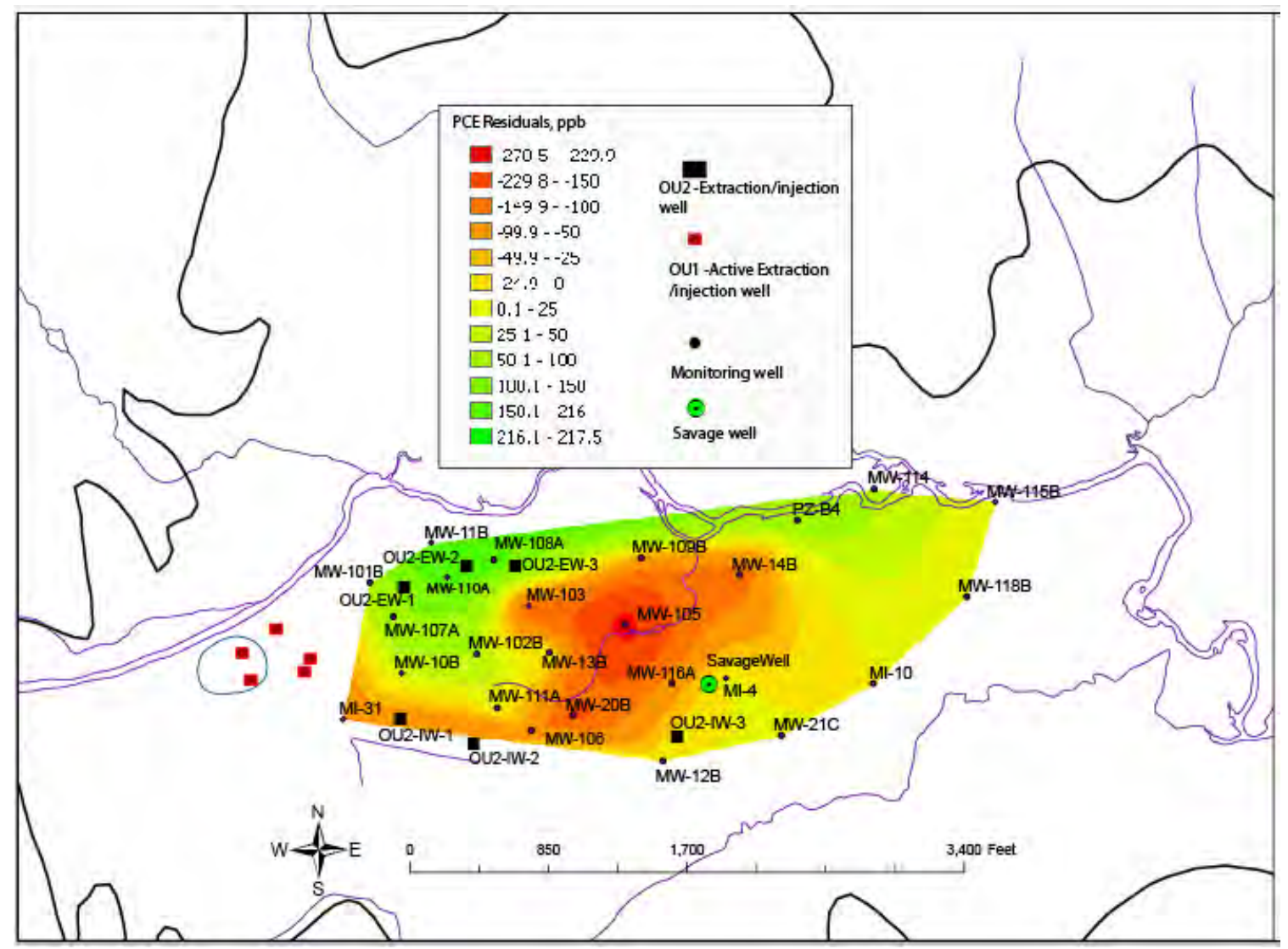

Figure 6. Map showing model residuals for tetrachloroethylene concentrations in 2010 for layer 3 of the remedial operational model. 


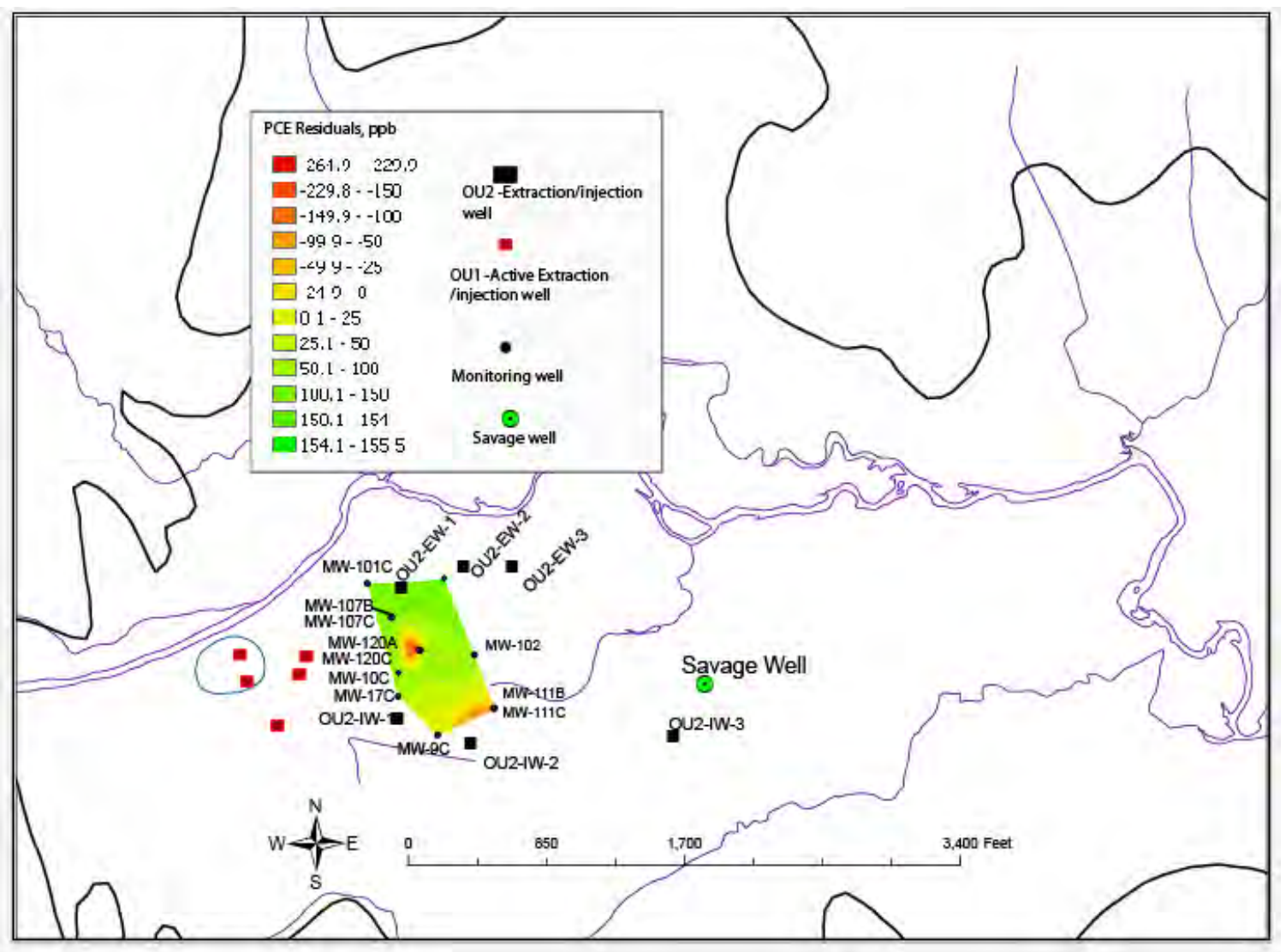

Figure 7. Map showing model residuals for tetrachloroethylene concentrations in 2010 for layers 4 and 5 of the remedial operational model.

\subsubsection{Tetrachloroethylene Mass}

Estimated PCE mass from observed PCE concentrations and ROM-computed PCE mass have been tracked over time. Figure 8 is a reproduction of a graph from Gradient Corp. (2009, fig. 3-18) showing PCE mass. Each curve on the graph represents the total PCE mass from both dissolved and sorbed PCE phases for the OU2 area only. The graphs can be used to estimate the attenuated mass of PCE for the MSGD aquifer. For example, from June 2007 to 2008, the observed PCE mass declined by $375 \mathrm{~kg}$, whereas the ROM-computed mass declined by $450 \mathrm{~kg}$. The spread between the two curves is decreasing over time, and the two curves are converging because the PCE mass computed from the ROM is decreasing at a faster rate than the observed PCE mass and the initial model mass exceeded the initial observed mass. 


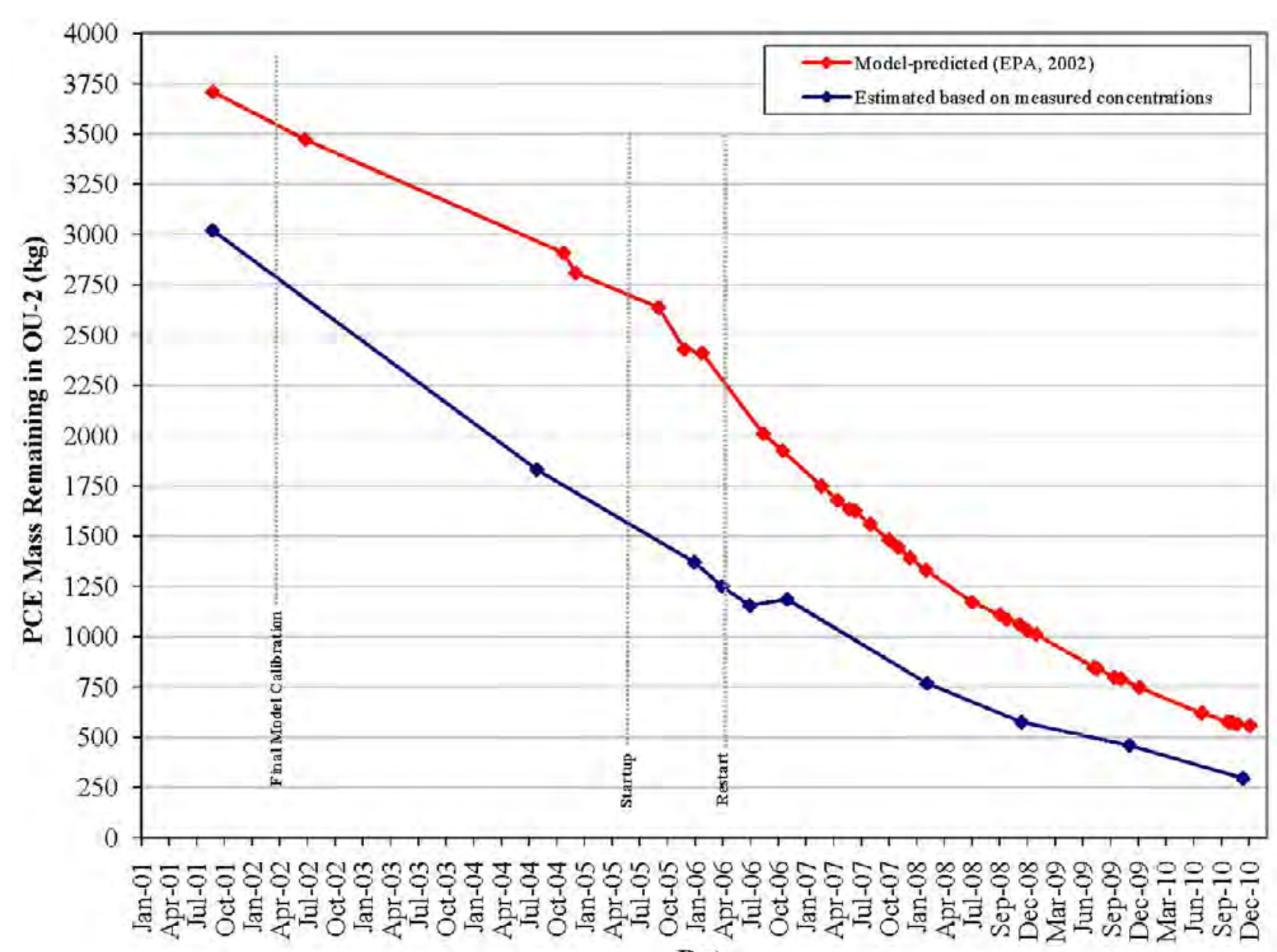

Date

Figure 8. Graph showing tetrachloroethylene mass. Graph is from Gradient Corp. (2009, fig. 3.18).

The above comparison indicates that the rate of attenuation of PCE in the ROM as shown by the decrease in PCE mass over time is too large. Ultimately, the mass computed by the ROM may become smaller than the estimated observed mass based on the differences in rates of attenuation. To rectify these differences, individual components of the solute transport budget could be examined to identify where adjustments could be made in the ROM to better replicate observed PCE concentrations and estimated observed rates of attenuation. For example, comparison between PCE mass extracted from OU2 remedy wells in the ROM with observations and estimates of mass extracted from the same wells would help determine if simulated capture areas and transport rates are reasonable approximations.

\section{Additional Simulations for Model Evaluation}

Simulated results from the ROM were compared to new simulations from the BM as an additional evaluation tool. This comparison allowed for an additional assessment of ROM results, provided for a further understanding of solute transport processes in the MSGD aquifer, and assisted in the evaluation of the predictive capabilities of the ROM.

Given the differences in model software, there are some numerical computational differences when simulating with the two models. These differences should be acknowledged prior to comparing model output. Differences in the results of simulations related to the numerical solution using the two 
different model codes (VMS-MT3D99, MOC3D) were previously investigated and shown to have a small effect on model output (USEPA, 2002). Therefore, model comparisons between the BM and the ROM (Gradient Corp., 2009) offer insight into the effect of model input, simulation period, temporal discretization, transport processes, and remedial operation, on model-output results.

\subsection{Comparison of Proposed Remedial Operations}

Simulations initially performed in USEPA (2002) assumed OU2 remedial operations started simultaneously with OU1 remedial operations in 1999. Simulations were also initially done assuming a 2-year lag time between the beginning of OU1 (1999) and OU2 (2001) remedial operations. Model output from the latter simulation is presented in this section (column 2; table 4) for the projected 2010 simulated year as performed in 2002 .

Table 4. Statistical summary of model-computed tetrachloroethylene concentrations at monitoring wells in operational unit 2 (OU2) from a simulation comparison of actual and proposed OU2 remedy operations using the remedial operational model and base model with a comparison to 2010 observations.

[Values are in parts per billion unless otherwise noted. Wells are shown in figure 1 and listed in appendix 1. OU2, operational unit 2; PCE, tetrachloroethylene; --, no data]

\begin{tabular}{lccc}
\hline \multicolumn{1}{c}{ Salient statistic } & $\begin{array}{c}\text { Remedial } \\
\text { operational model } \\
\text { PCE }^{1}\end{array}$ & $\begin{array}{c}\text { Base model } \\
\text { PCE }^{2}\end{array}$ & $\begin{array}{c}\mathbf{2 0 1 0} \text { observed } \\
\text { PCE }\end{array}$ \\
\hline OU2 remedy start time & 2005 & 2001 & 2005 \\
2001-OU2 PCE mass, in kilograms & 3,660 & 2,672 & -- \\
Mean & 65.9 & 4.4 & 51 \\
Minimum & 0.2 & 0 & 0 \\
Maximum & 381 & 34 & 410 \\
Standard deviation & 83.5 & 7.8 & 92.3 \\
Number of wells & 64 & 64 & 59 \\
\hline
\end{tabular}

${ }^{1}$ Actual OU2 remedy ending in the simulated year 2010, from Gradient Corp. (2009); remedy start time indicates the remedy started in 2005.

${ }^{2}$ Proposed OU2 remedy ending in the simulated year 2010; remedy start time indicates that simulated OU2 remedy began in 2001.

It appears that starting the OU2 remedy in 2001, as initially simulated in the BM, instead of the actual OU2 remedy start time in 2005 considerably affects model-computed PCE concentrations (table 4). Differences in mean model-computed PCE concentrations between the simulations are fairly large (65.9 ppb to $4.4 \mathrm{ppb)} \mathrm{and} \mathrm{maximum} \mathrm{computed} \mathrm{PCE} \mathrm{concentrations} \mathrm{differ} \mathrm{by} \mathrm{an} \mathrm{order} \mathrm{of} \mathrm{magnitude} \mathrm{(381}$ $\mathrm{ppb}$ to $34 \mathrm{ppb}$ ). If this was the primary reason for PCE differences, it would suggest that operating the OU2 remedial system for an additional 4 years would decrease concentrations below $100 \mathrm{ppb}$. However, to better evaluate model results and to assess model sensitivity to other factors (such as PCE mass) besides the start time of the OU2 remedy, additional simulations were tested (see discussion in sections 4.2-4.4).

\subsection{Comparison of Actual Remedial Operations}

Simulated extraction/injections in OU2 using the BM were adjusted to better represent actual OU2 remedy operations over time as reported by Gradient Corp. (Neal Grasso, Gradient Corp., December 23, 2010, written commun.). This step allowed for a more direct comparison of model output from the two models. Comparison of models using a similar OU2 remedy start time are provided in this section. 
The volumetric flow budgets for the models using a similar OU2 start time shows that the model-computed river leakage into the MSGD aquifer - the amount of streamflow lost to the MSGD aquifer is $1 \mathrm{ft}^{3} / \mathrm{s}$ greater in the ROM (Neal Grasso, Gradient Corp., December 23, 2010, written commun.) than the BM (table 5; River leakage input into the MSGD aquifer). This greater rate of river leakage may be problematic given that observed low flows in the Souhegan River are about $5 \mathrm{ft}^{3} / \mathrm{s}$ or 20 percent more than the model-computed river leakage.

Table 5. Volumetric budgets from models (remedial operational model and base model) for December 2009.

[Remedial operational model from Gradient Corp. (2009); base model from USEPA (2002) and Harte (2004). Input means flow into the Milford-Souhegan glacial-drift (MSGD) aquifer; output means flow out of the MSGD aquifer]

\begin{tabular}{|c|c|c|c|}
\hline \multicolumn{2}{|c|}{$\begin{array}{l}\text { Remedial operational model December } 2009 \text { output } \\
\text { (Stress period length about } 1 \text { month) }\end{array}$} & \multicolumn{2}{|c|}{$\begin{array}{l}\text { Base model December } 2009 \text { output } \\
\text { (Stress period length } 4.4 \text { years) }\end{array}$} \\
\hline \multicolumn{2}{|l|}{ Input(ft3/s) } & \multicolumn{2}{|l|}{ Input(ft3/s) } \\
\hline Constant head & 0 & Constant head & 0 \\
\hline Wells & 0.9113 & Wells & 0.7296 \\
\hline River leakage & 3.9881 & River leakage & 2.956 \\
\hline Head dependent & 0.4078 & Head dependent & 0.4321 \\
\hline \multirow[t]{2}{*}{ Recharge } & 3.1202 & Recharge & 3.2644 \\
\hline & & Storage & $9.07 \times 10^{-8}$ \\
\hline Total in & 8.4274 & Total & 7.3821 \\
\hline \multicolumn{2}{|l|}{ Output(ft3/s) } & \multicolumn{2}{|l|}{ Output(ft3/s) } \\
\hline Constant head & 0 & Constant head & 0 \\
\hline Wells & 5.1304 & Wells & 3.9432 \\
\hline River leakage & 3.0714 & River leakage & 3.3536 \\
\hline Head dependent & 0.1027 & Head dependent & 0.0847 \\
\hline \multirow[t]{2}{*}{ Recharge } & 0 & Recharge & 0 \\
\hline & & Storage & $3.70 \times 10^{-7}$ \\
\hline Total out & 8.3044 & Total & 7.3815 \\
\hline \multicolumn{2}{|l|}{ Net flow } & \multicolumn{2}{|l|}{ Net flow } \\
\hline Amount of net flow (input minus output) & 0.123 & Amount of net flow (input minus output) & 0.00062 \\
\hline Discrepancy, in percent & 1.47 & Discrepancy, in percent & 0.01 \\
\hline
\end{tabular}

The BM-computed PCE concentrations are less than the ROM PCE concentrations even after matching remedy operations (table 6). Differences in PCE between the two models are partly attributed to differences in the initial mass of simulated PCE. In 2001, PCE mass in OU2 was 2,814 $\mathrm{kg}$ for the BM whereas PCE mass was 3,660 kg for the ROM. Also, examination of model-computed PCE concentrations from the ROM shows that elevated PCE concentrations occur near the OU1 barrier wall from excessive dispersion of PCE across the barrier (fig. 9), which does not occur in the BM when the CHFB transport package of MODFLOW-GWT (Hornberger and others, 2002) is used. Higher rates of PCE transport from OU1 would potentially increase PCE mass in OU2. This process of excessive dispersion at the barrier wall was examined by Harte and others (2006) and was shown to result from numerical issues arising from problems with the dispersive equation (numerical dispersion) and simulation of low permeability barriers with the hydraulic barrier package of MODFLOW (Hsieh and Freckleton, 1993). The problem is correctable with the use of a modified CHFB transport package 
(Hornberger and others, 2002), which utilizes a new numerical solution to solve the advectivedispersive transport equation and allows for the assignment of a unique, low, dispersivity to the barrier. These high PCE concentrations are likely inflating PCE concentrations in parts of OU2, resulting in some of the differences between the two models (table 6). Observed PCE concentrations by OU1-EW1 and OU2-EW2 wells are less than $50 \mathrm{ppb}$ (Weston, Inc., 2009) and are at least $100 \mathrm{ppb}$ less than PCE concentrations computed with the ROM. Observation well PW-2D external to the barrier had a PCE concentration of $32 \mathrm{ppb}$ whereas the ROM computed a PCE concentration of more than $700 \mathrm{ppb}$.

Table 6. Statistical summary of model-computed tetrachloroethylene concentrations at monitoring wells in operational unit 2 (OU2) from a simulation of actual OU2 remedial operations using the remedial operational model and base model with a comparison to 2010 observations.

[Values are in parts per billion unless otherwise noted. Wells are shown in figure 1 and listed in appendix 1. PCE, tetrachloroethylene; --, no data]

\begin{tabular}{lccc}
\hline \multicolumn{1}{c}{ Salient statistic } & $\begin{array}{c}\text { Remedial operational } \\
\text { model PCE }\end{array}$ & $\begin{array}{c}\text { Base model } \\
\text { PCE }\end{array}$ & $\begin{array}{c}\text { 2010 observed } \\
\text { PCE }\end{array}$ \\
\hline OU2 remedy start time & 2005 & 2005 & 2005 \\
2001-OU2 PCE mass, in kilograms & 3,660 & 2,814 & -- \\
Mean & 65.9 & 10.5 & 51 \\
Minimum & 0.2 & 0 & 0 \\
Maximum & 381 & 85 & 410 \\
Standard deviation & 83.5 & 20.7 & 92.3 \\
Number of wells & 64 & 64 & 59 \\
\hline
\end{tabular}

${ }^{1}$ Actual OU2 remedy ending in the simulated year 2010, from Gradient Corp. (2009).

${ }^{2}$ Actual OU2 remedy ending in the simulated year 2010.

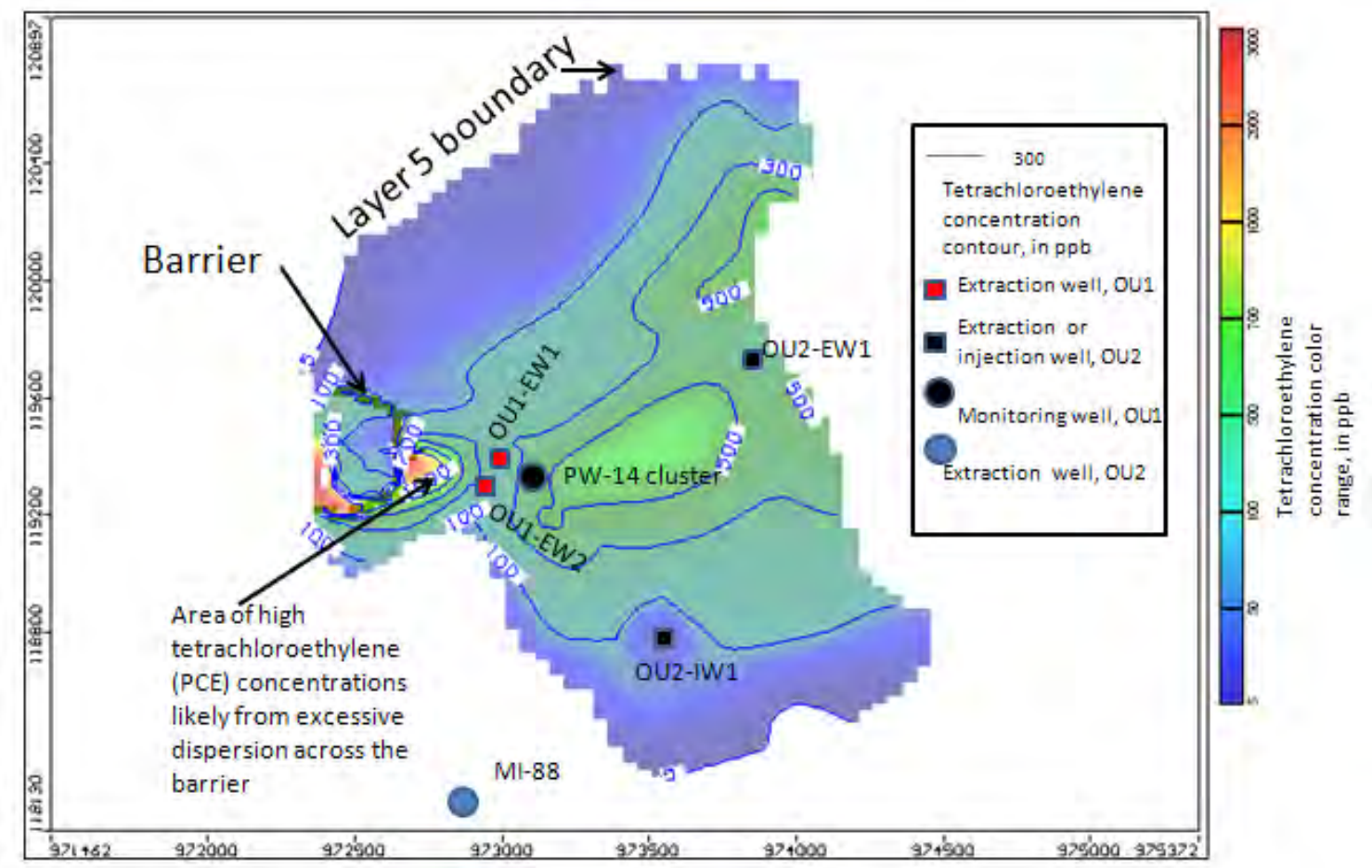

Figure 9. Map showing remedial operational model-computed tetrachloroethylene (PCE) concentrations showing elevated PCE by the operational unit 1 (OU1) barrier. Data from Visual MODFLOW files (Gradient Corp., January 
2009, written commun.). Model-computed PCE concentrations in the remedial operational model for the OU1-EW1 and OU1-EW2 wells are too high (about 200 parts per billion) compared with observed data and indicate that the excessive dispersion of PCE across the barrier, from high PCE concentrations inside the barrier, is likely elevating PCE concentrations outside the barrier.

Although the ROM is overestimating dispersion across the barrier, gross model PCE residual statistics match observations better than the BM. However, examination of residual PCE show spatial bias as presented in the section on residual analysis. Two conclusions can be inferred from this comparison, including the initial mass estimates used in the ROM (Gradient Corp., 2002) better approximates actual mass, and the rate of attenuation in the ROM may be too high in some areas.

\subsection{Model Adjustments}

The previous model comparisons indicate that the simulated rate of attenuation in the models (both BM and ROM) may be too large in some areas of the aquifer. Comparisons also suggest that the initial starting mass should be at least 4,226 kg of PCE as used in the ROM simulations by Gradient Corp. $(2002,2009)$ and that the initial starting mass $(2,700 \mathrm{~kg})$ used in some of the BM simulations may be too low.

Observed PCE concentrations in the lowermost layers of the aquifer, such as layer 5 of the ROM, were more than 400 ppb as of 2010 (Neal Grasso, Gradient Corp., February 15, 2011, written commun.) whereas model-computed PCE concentrations typically underestimated concentrations in that layer. One important controlling factor in the rate of attenuation and solute transport of PCE is the retardation factor. To test the effect of retardation on PCE concentrations in layer 5, the retardation was increased from 2.5 to 4 for that layer in the BM. Results are provided in table 7 and show that the maximum model-computed PCE concentration increased from $85 \mathrm{ppb}$ (table 7) to $281 \mathrm{ppb}$ (table 8).

Table 7. Statistical summary of model-computed tetrachloroethylene concentrations at monitoring wells in operational unit 2 (OU2) from a simulation of actual OU2 remedy operations (remedial operational and base models) and adjustment of retardation factor for layer 5 (base model) with a comparison to 2010 observations.

[Values are in parts per billion unless otherwise noted. Wells are shown in figure 1. PCE, tetrachloroethylene; --, no data]

\begin{tabular}{lccc}
\hline \multicolumn{1}{c}{ Salient statistic } & $\begin{array}{c}\text { Remedial operational } \\
\text { model PCE }\end{array}$ & $\begin{array}{c}\text { Base model } \\
\text { PCE }^{2} \\
\text { (Retardation } \\
\text { adjusted) }\end{array}$ & $\begin{array}{c}\text { 2010 observed } \\
\text { PCE }\end{array}$ \\
\hline OU2 remedy start time & 2005 & 2005 & 2005 \\
2001-OU2 PCE mass, in kilograms & 3,660 & 3,183 & -- \\
Mean & 65.9 & 22.8 & 51 \\
Minimum & 0.2 & 0 & 0 \\
Maximum & 381 & 281 & 410 \\
Standard deviation & 83.5 & 47.4 & 92.3 \\
Number of wells & 64 & 62 & 59 \\
\hline
\end{tabular}

${ }^{1}$ Actual OU2 remedy ending in the simulated year 2010, from Gradient Corp. (2009).

${ }^{2}$ Actual OU2 remedy ending in the simulated year 2010 . 
Table 8. Statistical summary of model-computed tetrachloroethylene concentrations at monitoring wells in operational unit 2 (OU2) from a simulation of actual OU2 remedy operations (remedial operational and base models) and adjustment of starting mass ( 36 percent increase) for layer 5 (base model) with a comparison to 2010 observations.

[Values are in parts per billion unless otherwise noted. Wells are shown in figure 1.PCE, tetrachloroethylene; --, no data]

\begin{tabular}{lccc}
\hline \multicolumn{1}{c}{ Salient statistic } & $\begin{array}{c}\text { Remedial operational } \\
\text { model PCE }\end{array}$ & $\begin{array}{c}\text { Base model } \\
\text { PCE }^{2} \\
\text { (mass } \\
\text { increased) }\end{array}$ & $\begin{array}{c}\text { 2010 observed } \\
\text { PCE }\end{array}$ \\
\hline OU2 remedy start time & 2005 & 2005 & 2005 \\
2001-OU2 PCE mass, in kilograms & 3,660 & 3,431 & -- \\
Mean & 65.9 & 28.1 & 51 \\
Minimum & 0.2 & 0 & 0 \\
Maximum & 381 & 361 & 410 \\
Standard deviation & 83.5 & 62 & 92.3 \\
Number of wells & 64 & 62 & 59 \\
\hline
\end{tabular}

${ }^{1}$ Actual OU2 remedy, ending in the simulated year 2010, from Gradient Corp. (2009).

${ }^{2}$ Actual OU2 remedy, ending in the simulated year 2010.

The comparison in table 7 highlights that an improved match between model and observed PCE can be made if a higher retardation factor is used in layer 5 of the BM. However, it still is apparent from the comparison that the initial starting mass of PCE is underestimated in the BM. Increasing the retardation in layer 5 increases simulated PCE mass from 2,814 to 3,183 kg, which is still less than the simulated mass in the $\operatorname{ROM}(3,660$; tables 4 and 6 of this report). Therefore, an additional simulation was done with added mass in layer 5 only (starting mass was increased by 36 percent in layer 5 ) that resulted in additional improvement in the model-computed PCE concentrations (table 8). Maximum model-computed PCE concentration increased from $281 \mathrm{ppb}$ (table 6) to $361 \mathrm{ppb}$ (table 7) in the BM.

A graph of residual PCE from simulation results (table 8) shows the tendencies for both models (the ROM and the BM with the option of high retardation in layer 5) to underpredict PCE concentrations in high PCE concentration areas of the aquifer (fig. 10). However, for low PCE concentration areas of the aquifer, model-computed PCE from the BM better matches observed PCE concentrations suggesting that transport properties in the BM in those simulated areas of the aquifer are representative of field conditions as a whole. In addition, excessive dispersion across the barrier in the ROM may play a role in overestimating PCE concentration in parts of the MSGD aquifer. 


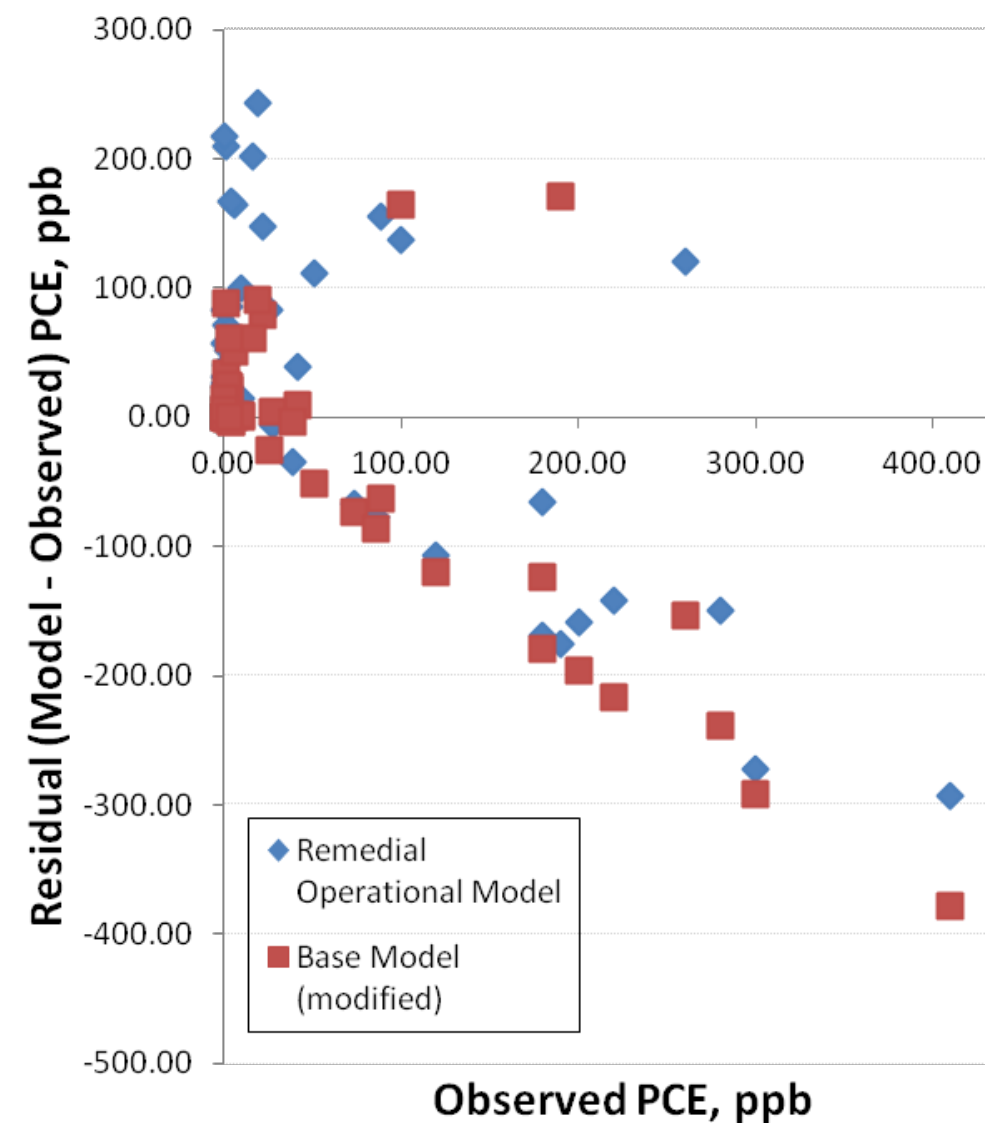

Figure 10. Chart showing model residual tetrachloroethylene (PCE) concentrations and observed PCE concentrations residuals in December 2010 for the simulation presented in table 8. Large residuals at high PCE concentrations suggest underestimation of initial mass. Data are from Gradient Corp. (February 15, 2011, written commun.].

\subsection{Additional Sources of Tetrachloroethylene}

The comparison of models and new simulations performed for this study indicate that PCE mass is likely underestimated in the MSGD. Previous work by Harte (2004) also reported that PCE mass along the southern boundary of the plume may be greater than previously estimated. The analysis presented here also indicates that PCE mass in the lower parts of the aquifer may be greater than previously estimated. Additional mass of PCE may also be present near the boundary of OU1 and OU2 from back diffusion of PCE in high-carbon content or low-permeability layers or from previously unaccounted areas with dissolved and sorbed PCE (a larger plume than anticipated). Figure 11 shows differences in observed PCE declines from different depths in the MSGD aquifer and differences in model-computed PCE declines from analogous or corresponding model layers. The wells are located near the boundary of OU1 and OU2. 


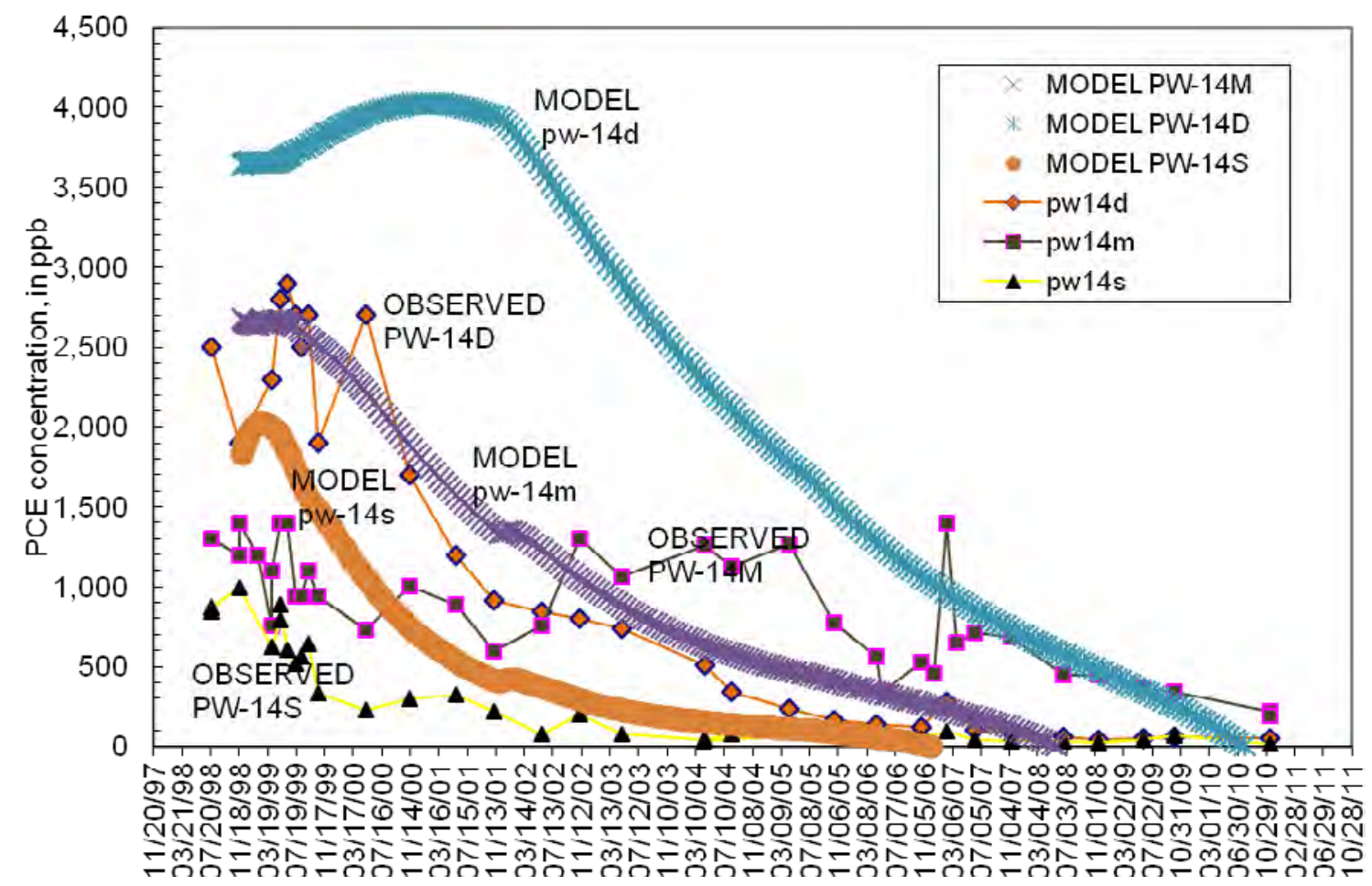

Figure 11. Graph of model-computed tetrachloroethylene (PCE) concentrations (base model) and observed PCE concentrations for PW-14 cluster wells. Consistently high PCE concentrations at well PW-14M suggest additional mass of PCE in aquifer.

A larger PCE plume than anticipated and/(or) higher amounts of sorbed PCE from sediments with a high carbon content will lead to slow rates of dissolved PCE declines in the aquifer. Observed PCE concentrations illustrate the effect of these processes on sustaining PCE concentrations in the aquifer at the PW-14 (s,m,d) well cluster (fig. 11). Observed PCE concentrations from the PW-14M well show increasing and consistently high PCE concentrations from 2001 through 2005, whereas declines are large (several hundred parts per billion) for wells PW-14S and PW-14D. Model-computed PCE concentrations for wells PW-14S and PW-14D show higher concentrations than observed but similar rates of decline. In contrast, model-computed PCE for PW-14M shows a steady decline unlike observed PCE concentrations, indicating unaccounted for PCE mass (a larger plume than anticipated) is likely sustaining observed concentrations for a period of time (2001-2009). Additional PCE mass or potential source areas in OU1 were discussed by Camp, Dresser, and McKee, Inc. (2001) and can include additional mass from a larger PCE plume and (or) increased amount of PCE adsorption sites.

\section{Summary of Findings and Conclusions}

The model evaluation and assessment done for this study is meant to provide insight that would allow for an improved simulation of PCE through model enhancements. The improvements in simulation would facilitate the evaluation of solute transport processes in the aquifer, and better assess remedial performance. During the evaluation of the simulations, it became apparent that several model adjustments could be made to improve model simulations and fit of the Savage Superfund site PCE plume, including the following: 
increase retardation in lower layers of the aquifer from 2.5 to 4

adjust well extraction and injection rates to better match actual conditions

consider converting the river package to the streamflow routing package to ensure river leakage does not exceed streamflow

accurately monitor the rate of extraction (if any) from the MI- 88 well and the amount of discharge in the adjacent ditch

correct well extraction and injection rates and assignment of model layers at several wells (table 2)

decrease numerical dispersion across the OU1 barrier

reassess the amount of tetrachloroethylene (PCE) mass assigned to the model, which is likely higher in several areas of the aquifer than previously estimated

Underestimation of plume mass appears to be problematic in model simulations and can be partly addressed by adjusting initial PCE mass assigned to the model by varying interpolation schemes and assumptions to account for alternative PCE realizations (different spatial distribution patterns of PCE concentrations). The sensitivity of the alternative PCE realizations to produce substantial changes in PCE mass could be examined, prior to incorporation into the model as initial PCE concentrations, by selecting appropriate PCE mass amounts that better reflect likely field conditions.

Upon making these improvements, the remedial operations model (ROM) could be rerun to potentially improve upon the predictive capability of the model and estimation of PCE remedial time frames. In addition, the model would probably benefit from a calibration of recent data. The ROM has not been calibrated to observed PCE concentrations since 2002 and an additional 9 years (as of 2011) of PCE data are available. Whereas a comparison has been done between model results and observed data from operational unit 2 (OU2) wells, the comparison was done without the benefit of calibration. Model calibration includes the adjustment of model input and simulation conditions to improve the match between model results and observed data. Automated calibration procedures can be employed efficiently to expedite the calibration process. An improved ROM can then be used to assess remedy operational conditions and whether adjustments are warranted to expedite the remediation of PCE. This assessment can be extended to OU1, particularly to areas outside the barrier.

Further PCE residual analysis could potentially benefit from inclusion of wells within the OU1 remedy area that are outside the barrier, including PW13, PW14, and MW16 cluster wells. A comparison of the extracted mass from OU2 remedy extraction wells (EW1, EW2, EW3) to modelcomputed extracted mass could also offer further insight into the remediation of PCE in the aquifer. Residual statistics could be used to graph model-computed and observed PCE concentrations for selected wells, particularly in lower layers of the aquifer.

\section{Use of Model as a Predictive Tool}

The model evaluation and analysis was aimed at assessing the ROM as a predictive tool in quantifying PCE transport and assessing the effectiveness of remedial operations. Understanding ROM (and the BM) model ${ }^{5}$ limitations will help in this effort. Also, the improvements suggested to the ROM could help and assist in the use of the model to test whether remedial operational changes are warranted to expedite the remedy. The following example serves as an illustration of the utility of models to help evaluate PCE trends in the aquifer based on transport properties and remedial operations.

Slow recalcitrant zones of PCE (slow transport and attenuation) are observed in several areas of the aquifer. Given the current remedial infrastructure, the model could be used to test if modifications in extraction and injection can accelerate flushing more efficiently in these areas. Under current remedial operations, projected maximum model-computed PCE concentrations in OU2 is shown in figure 12 for

\footnotetext{
${ }^{5}$ Model limitations of the BM are described in Harte (2006, 2006).
} 
a simulation where the retardation factor for layer 5 has been adjusted upward to 4 from 2.5, increasing the amount of sorbed mass on aquifer sediments. With this increase, a maximum PCE concentration in OU2 of 42 parts per billion occurs by 2020 in the simulation. This simple example illustrates the utility of models to help evaluate PCE trends in the aquifer based on transport properties and remedial operations.

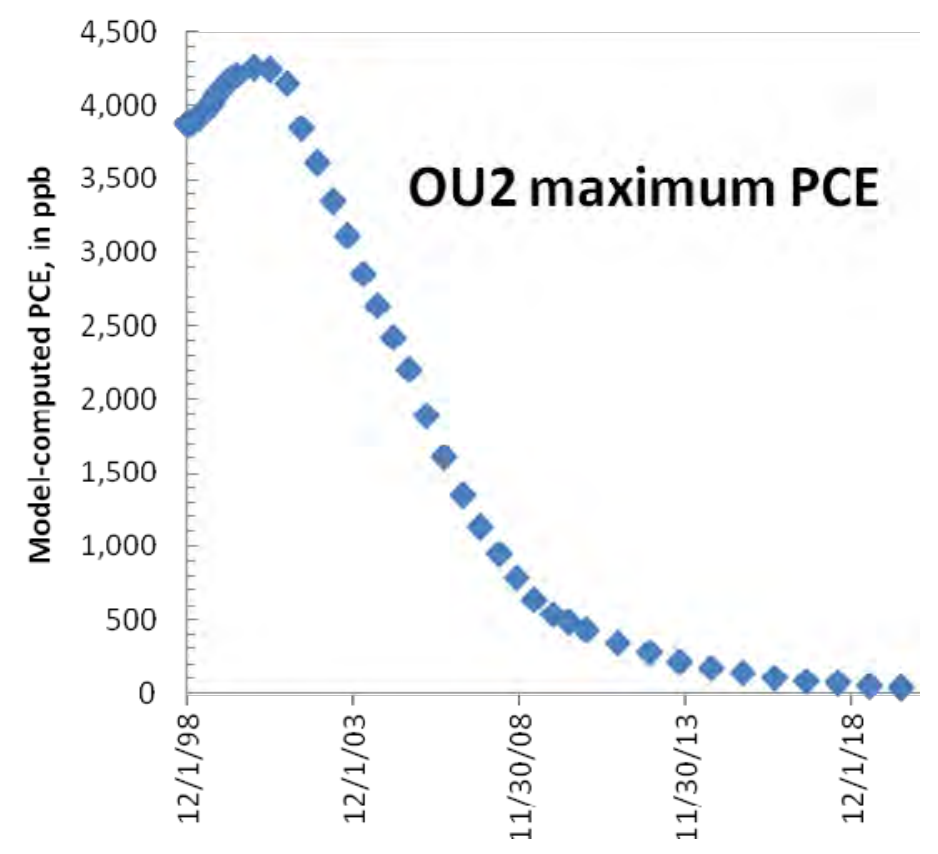

Figure 12. Graph of model-computed tetrachloroethylene (PCE) concentrations (base model) showing maximum PCE concentrations in OU2 under current remedial operation with a high retardation factor in layer 5 . In the simulation, a maximum PCE concentration of 500 parts per billion (ppb) is achieved in 2010, decreasing to $42 \mathrm{ppb}$ in 2020 .

Other enhancements to the model would help improve its utility in addressing remedial questions. New receptors or withdrawal wells (if any) in the MSGD aquifer can be simulated to identify their probability of capturing PCE, affecting the water budget, and (or) altering flowpaths. New withdrawal wells from residential housing have been installed in the underlying bedrock over the past 10 to 15 years (Genevieve Al-Egaily, New Hampshire Department of Environmental Services, August 2, 2010, written commun.). The ROM does not simulate flow and transport in the underlying bedrock. In addition, the model can be used to suggest where new monitoring well data would be useful to assess remedy performance.

The model resolution or discretization is too coarse inside the barrier wall in OU1 and cannot simulate all transport processes in that area without further model enhancements. Active remediation with in situ chemical oxidation (ISCO) has accelerated clean up of PCE inside the barrier, and PCE concentrations have decreased (Weston, Inc., 2009). Nevertheless, the potential for long-term transport of PCE across and under the barrier exists; numerical simulation can help assess this process. In particular, automatic calibration of model-computed PCE concentrations to observed PCE concentrations for areas outside of the barrier would greatly facilitate estimation of leakage of PCE from inside the OU1 containment area. This assessment would help evaluate the need for continued operation 
of OU1 remedial extraction and injection wells for purposes of capturing PCE transport in OU1 and decreasing PCE transport into OU2.

\section{References Cited}

Camp, Dresser, and McKee, Inc., 2001, Summary of investigations Re: Draining of bulk solvent storage tank, OK tool/Savage Municipal Well Superfund site, Milford, New Hampshire: Cambridge, Mass., Camp, Dresser, and McKee, Inc., November, variously paginated.

Gradient Corp., 2002, Draft remedial design investigation (RDI) report Savage Well Superfund site, Milford, New Hampshire: Cambridge, Mass., Gradient Corp., May 3.

Gradient Corp., 2008, Draft annual groundwater quality monitoring report-2007, Savage Well Superfund site, Milford, New Hampshire: Cambridge, Mass., Gradient Corp., July 23.

Gradient Corp., 2009, Draft annual groundwater quality monitoring report—2008, Savage Well Superfund site, Milford, New Hampshire: Cambridge, Mass., Gradient Corp., June 11.

Harbaugh, A.W., Banta, E.R., Hill, M.C., and McDonald, M.G., 2000, MODFLOW-2000, the U.S. Geological Survey modular ground-water model-User guide to modularization concepts and the ground-water flow process: U.S. Geological Survey Open-File Report 2000-92, 121 p.

Harbaugh, A.W., and McDonald, M.G., 1996, User's documentation for MODFLOW-96, an update to the U.S. Geological Survey modular finite-difference ground-water flow model: U.S. Geological Survey Open-File Report 96-485, 56 p.

Harte, P.T., 2004, Simulation of source transport of tetrachloroethylene in ground water of the glacialdrift aquifer at the Savage Municipal Well Superfund site, Milford, New Hampshire, 1960-2000: U.S. Geological Survey Scientific Investigations Report 2004-5176, 78 p.

Harte, P.T., 2006, Effects of a remedial system and its operation on volatile organic compoundcontaminated ground water, operable unit 1, Savage Municipal Well Superfund site, Milford, New Hampshire, 1998-2004: U.S. Geological Survey Scientific Investigations Report 2006-5083, 80 p. Harte, P.T., Flynn, R.J., and Mack, T.J., 1999, Construction and calibration of numerical ground-waterflow models of the western half of the Milford-Souhegan glacial-drift aquifer, Milford, New Hampshire: U.S. Geological Survey Open-File Report 99-462, 76 p.

Harte, P.T., Konikow, L.F., and Hornberger, G.Z., 2006, Simulation of solute transport across lowpermeability barrier walls: Journal of Contaminant Hydrology, 85 (3-4), p. 247-270.

Heberton, C.I., Russell, T.F., Konikow, L.F., and Hornberger, G.Z., 2000, A three-dimensional finitevolume eulerian-lagrangian localized adjoint method (ellam) for solute-transport modeling: U.S. Geological Survey Water-Resources Investigations Report 00-4087, 63 p.

Hornberger, G.Z., Konikow, L.F., and Harte, P.T., 2002, Simulating solute transport across horizontalflow barriers using the MODFLOW ground-water transport process: U.S. Geological Survey OpenFile Report 2002-52, 28 p.

Hsieh, P.A., and Freckleton, J.R., 1993, Documentation of a computer program to simulate horizontalflow barriers using the U.S. Geological Survey's modular three-dimensional finite-difference groundwater flow model: U.S. Geological Survey Open-File Report 92-477, 32 p.

Konikow, L.F., Goode, D.J., and Hornberger, G.Z., 1996, A three-dimensional method of characteristics solute-transport model (MOC3D): U.S. Geological Survey Water-Resources Investigations Report 964267, $87 \mathrm{p}$.

U.S. Environmental Protection Agency (USEPA), 2001, Comprehensive five-year review guidance: U.S. Environmental Protection Agency USEPA 540-R-01-007, 60 p.

U.S. Environmental Protection Agency (USEPA), 2002, Remedial design report, Savage Municipal Well Superfund site, Milford, New Hampshire: Tetra Tech NUS, Inc., Mass., variously paginated. 
U.S. Geological Survey, 2011, MF2K-GWT-Three-dimensional ground-water flow and solutetransport model integrated with MODFLOW-2000: U.S. Geological Survey, accessed December 19, 2011, at http://water.usgs.gov/nrp/gwsoftware/mf2k_gwt/mf2k_gwt.html.

Weston, Inc., 2009, Draft 2009 annual report_-Savage Municipal Well Superfund site, Milford, New Hampshire: Concord, N.H., Weston Solutions, Inc.

Zheng, Chunmiao, 1990, MT3D, A modular three-dimensional transport model for simulation of advection, dispersion and chemical reactions of contaminants in groundwater systems: U.S. Environmental Protection Agency, 170 p.

Zheng, Chunmiao, and Wang, P.P., 1999, MT3DMS, a modular three-dimensional multi-species transport model for simulation of advection, dispersion and chemical reactions of contaminants in groundwater systems; documentation and users guide: Vicksburg, Miss., U.S. Army Corps of Engineers Research and Development Center contract report SERDP-99-1, 202 p. 


\section{Appendix 1. Listing of Wells Used in the Residual Analysis}

[Separately linked Excel file; click here] 